\title{
Cultura gaúcha e separatismo no Rio Grande do Sul
}

\author{
Caroline Kraus Luvizotto
}

LUVIZOTTO, CK. Cultura gaúcha e separatismo no Rio Grande do Sul [online]. São Paulo: Editora UNESP; São Paulo: Cultura Acadêmica, 2009. 93 p. ISBN 978-85-7983-008-2. Available from SciELO Books <http://books.scielo.org>.

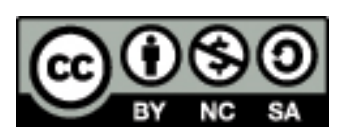

All the contents of this chapter, except where otherwise noted, is licensed under a Creative Commons Attribution-Non Commercial-ShareAlike 3.0 Unported.

Todo o conteúdo deste capítulo, exceto quando houver ressalva, é publicado sob a licença Creative Commons Atribuição Uso Não Comercial - Partilha nos Mesmos Termos 3.0 Não adaptada.

Todo el contenido de este capítulo, excepto donde se indique lo contrario, está bajo licencia de la licencia Creative Commons Reconocimento-NoComercial-CompartirIgual 3.0 Unported. 


\section{CULTURA GAÚCHA E SEPARATISMO NO RIO GRANDE Do SUL}

CAROLINE KRAUS LUVIZOTTO 


\section{Cultura gaúcha E SEPARATISMO NO Rio GRANDE Do Sul}



CAROLINE KRAUS LUVIZOTTO

\section{Cultura gaúcha E SEPARATISMO NO RIO GRANDE DO SUL}




\section{(C) 2009 Editora UNESP}

\section{Cultura Acadêmica}

Praça da Sé, 108

01001-900 - São Paulo - SP

Tel.: (0xx11) 3242-7171

Fax: (0xx11) 3242-7172

www.editoraunesp.com.br

feu@editora.unesp.br

CIP - Brasil. Catalogação na fonte

Sindicato Nacional dos Editores de Livros, RJ

L993C

Luvizotto, Caroline Kraus

Cultura gaúcha e separatismo no Rio Grande do Sul / Caroline Kraus Luvizotto. São Paulo: Cultura Acadêmica, 2009.

Inclui bibliografia

ISBN 978-85-7983-008-2

1. Gaúchos - Rio Grande do sul - Identidade étnica.

2. Identidade social - Rio Grande do Sul. 3. Regionalismo Rio Grande do Sul. 4. Características nacionais brasileiras. I. Título.

09-6050.

CDD: 305.80098165

CDU: $316.347(816.5)$

Este livro é publicado pelo Programa de Publicações

Digitais da Pró-Reitoria de Pós-Graduação da Universidade Estadual Paulista "Júlio de Mesquita Filho" (UNESP)

Editora afiliada:

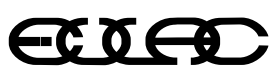

Asociación de Editoriales Universitarias de América Latina y el Caribe

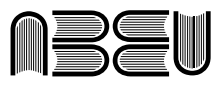

Associação Brasileira de Editoras Universitárias 
A meu Deus e Senhor, pelo dom da vida. A minha fantástica familia, pela compreensão e amor a mim dedicados. E ao Sol, que brilha, aquece e alegra os meus dias. 



\title{
SUMÁRIO
}

\author{
Apresentação 9 \\ Introdução 11 \\ 1 O Rio Grande do Sul e o gaúcho 15 \\ 2 Etnicidade e identidade étnica 29 \\ 3 O separatismo no Rio Grande do Sul 37 \\ 4 Tradição separatista 59 \\ 5 O nazismo no Rio Grande do Sul 75
}

Considerações finais 85

Referências bibliográficas 89 



\section{Apresentação}

A ideia de compor este trabalho surgiu durante a graduação em Ciências Sociais na Faculdade de Filosofia e Ciências de Marília - Unesp/FFC. Desde o início, o foco dos estudos foi o estado do Rio Grande do Sul. Abordou-se inicialmente a história da colonização alemã no estado, e depois se estabeleceu uma relação entre essa colonização alemã, seus aspectos políticos, sociais e culturais e o movimento separatista que se espalhava pelos estados do sul do Brasil no início da década de 1990. Percebeu-se que a questão ia muito além dessa relação.

Estudos sobre separatismo ou sobre etnicidade no Brasil existem muitos. Mas a abordagem que se propõe aquié discutir etnicidade e separatismo, utilizando como estudo de caso o estado do Rio Grande do Sul e o Movimento Separatista Sulino contemporâneo, tendo como pano de fundo a cultura gaúcha. Pretende-se demonstrar como esses dois conceitos interagem no caso desse movimento separatista que tem por objetivo emancipar o estado do Rio Grande do Sul do Brasil.

O trabalho apresenta primeiramente um panorama da discussão sobre o conceito de etnicidade a partir de autores clássicos, como Fredrik Barth, Philippe Poutgnat e Guilher- 
mo Rubem, entre outros. Apresenta também uma discussão sobre separatismo, baseada nos autores Manuel Andrade, João Nascimento Franco e Newton Duarte Molon, e sobre o Movimento Separatista Sulino contemporâneo, tomando-se como ponto de partida uma pesquisa de campo realizada em 1999 (cf. Luvizotto, 2000), composta de questionários e do estudo dos documentos do próprio movimento separatista. O trabalho também contempla uma reconstrução histórica sobre o Estado do Rio Grande do Sul em seus principais aspectos (colonização, tradições, revoluções), utilizando autores especializados nesse campo: Sandra J. Pesavento, Giralda Seyferth, Emilio Willens, Josef Love e Vera S. Zattera, entre outros. Finalmente, são relacionados os conceitos de etnicidade e separatismo aplicados ao caso do Estado gaúcho.

Este livro baseia-se na dissertação de mestrado defendida no Programa de Pós-graduação em Ciências Sociais, em 19 de dezembro de 2003, sob a orientação da professora doutora Christina de Rezende Rubim, na Faculdade de Filosofia e Ciências de Marília. 


\section{INTRODUÇÃO}

O regionalismo sul-rio-grandense e suas expressões estão alicerçados em tradições e em conhecimentos obtidos pela convivência de diferentes grupos que contribuíram para a formação histórica e cultural do sul do país e para a construção de uma identidade comum, somados aos elementos históricos e sociológicos. Seus legados e sua tradição são transportados para as gerações seguintes, sujeitos às mudanças próprias de cada época e circunstância.

Quando se analisa a história do gaúcho, ${ }^{1}$ pode-se observar que há certa resistência na interação com a sociedade nacional, interação esta inevitável. No entanto, o que chama atenção é o fato de alguns gaúchos não admitirem, até certo ponto, essa interação e tentarem se manter como um grupo homogêneo e distante dos outros, mesmo nos dias atuais com ressalvas, é claro.

Existe uma forte identidade entre os gaúchos, uma herança cultural baseada em tradições e costumes que são transmitidos de forma arraigada de geração para geração. É

1 Quando nos referirmos à população do Estado do Rio Grande do Sul, utilizaremos o termo gaúcho. 
esse respeito e apego aos aspectos de sua história, cultura, região que torna o gaúcho singular em relação aos habitantes das demais regiões do País.

O que torna este estudo relevante é a questão da preservação da identidade, aqui, especificamente, a dos gaúchos. Como destaca Guillermo Raul Ruben (1992, p.91), “[...] a identidade é um velho problema no pensamento social brasileiro" e éainda uma discussão substancial nas Ciências Sociais. Segundo o autor, a identidade "[...] transforma-se numa noção interna a uma teoria geral da sociedade" por ser o Brasil uma nação substancialmente jovem e plural, e, portanto, compreender nesse contexto a consciência de uma identidade pela população do sul do País.

O estudo da identidade é necessário para compreender o Brasil nos dias atuais, principalmente no que se refere aos movimentos sociais de caráter étnico (Ruben, 1992, p.96). No caso dos gaúchos, o estudo de sua identidade cultural faz-se indispensável para compreender a constituição do estado do Rio Grande do Sul e a criação de movimentos sociais, como o Movimento Separatista Sulino contemporâneo (Luvizotto, 2000).

Segundo alguns autores, como Bella Feldman-Bianco (1987), as Ciências Sociais possuem uma tradição já acumulada sobre as relações entre diferentes grupos étnicos e a sociedade envolvente. Deve-se destacar a antropologia da ação que se desenvolveu após a Segunda Guerra Mundial na Inglaterra a partir de pesquisas de campo, realizadas principalmente nas colônias europeias na África, e que tinha como objetivo central enfatizar as mudanças sociais no encontro entre diferentes culturas.

Destaca-se também a obra de Roberto Cardoso de Oliveira (1964), o autor brasileiro que, a partir dessa perspectiva, desenvolveu a Teoria da Fricção Interétnica na década de 1960, privilegiando a problemática dos conflitos nas relações entreas sociedades tribais e a sociedade nacional. Para Oliveira(1964, p.27): 
[... não se trata de relações entre entidades contrárias, simplesmente diferentes ou exóticas, umas em relação a outras; mas, contraditórias, i.e., que a existência de uma tende a negar a outra. E não foi por outra razão que nos valemos do termo fricção interétnica para enfatizar a característica básica da situação de contato entre índios e a sociedade nacional.

Finalmente, há os denominados estudos de aculturação desenvolvidos quase na mesma época pelos antropólogos americanos e que no Brasil ficaram conhecidos como estudos de comunidades, ${ }^{2}$ desdobrando-se em várias pesquisas: Cunha, tradição e transição em uma cultura rural do Brasil (Willems, 1947), "Evolução da estrutura social de Guaratinguetá num período de trezentos anos” (Hermann, 1948), Cruz das almas: a Brazilian Village (Pierson, 1951)e Amazon town: a study of man in the tropics (Wagley, 1953).

Não se pode negar que a aparição de movimentos separatistas deixa entrever alguns problemas inerentes à Federação brasileira, a iniciar-se pela contradição entre identidade nacional e as várias identidades regionais. Além disso, demonstra a tensão entre propostas de centralização e descentralização administrativa, a luta por recursos econômicos, que ocorrem tanto no plano nacional quanto no regional e intraestadual. Nesse contexto, destaca-se a luta entre os diversos estados por maior representatividade no Congresso e autonomia nas decisões que dizem respeito a sua região.

Darcy Ribeiro (1995, p.413) explica a tendência separatista gaúcha, o que precisamente interessa neste estudo, a partir de fatores geográficos, políticos e históricos:

2 Segundo Rubim(1997, p.57), "Estes estudos tinham como principal objetivo a aplicação de ações práticas na realidade social brasileira. Os critérios de escolha das comunidades eram: nunca terem sido estudadas anteriormente, a sua representatividade perante uma série de outras comunidades análogas, e a ampliação ou repercussão de um fato econômico ou político local”. 
Diversos fatores se conjuraram para ativar essas tendências separatistas. Entre eles, o fato de ser uma vasta e longínqua região com interesses próprios irrenunciáveis e que, não sendo adequadamente atendidos, ensejavam tensões disruptivas conducentes à ruptura com o poder central. Soma-se a isso a circunstância de viver apartada do resto do Brasil e submetida a influências intelectuais e políticas de centros urbanos culturalmente avançados, como Montevidéu e Buenos Aires. Nessas condições, não podiam deixar de surgir aspirações de independência, inspiradas às vezes de que o Sul melhor realizaria suas potencialidades como um país autônomo do que como um estado federado; motivadas outras vezes por ideários políticos arrojados, como as lutas anti-escravistas e a campanha republicana dos farrapos.

A singularidade do gaúcho destacada neste trabalho pouco pode demonstrar da riqueza cultural dessa população. A intenção em reconstruir alguns aspectos da história do Rio Grande do Sul é a de permitir a configuração do processo de formação de um ideal separatista que, mesmo não sendo unânime, é representativo no Brasil de uma tendência mundial, ante todo um denominado processo de globalização, do afloramento de identidades específicas, de acordo com Lévi-Strauss (1980) em Raça e história. Por isso, tentar-se-á estabelecer uma relação entre conceitos como separatismo e identidade étnica, na medida em que se compreende o significado desta última, a partir da complexidade da especificidade do grupo étnico em questão: os gaúchos. 


\section{1 \\ O Rio Grande do Sul E O GAÚCHO}

A história da ocupação e do povoamento do estado do Rio Grande do Sul está demarcada pela questão fronteiriça. Região-limite entre dois impérios - o espanhol, com sede em Buenos Aires no Rio da Prata, e o português, com sede no Rio de Janeiro -, o chamado Continente de São Pedro do Rio Grande do Sul, desde o século XVII, foi permanentemente disputado pelas duas coroas ibéricas.

Teoricamente, pelo Tratado de Tordesilhas de 1493, a linha que separava os dois reinos católicos passava, em sua extensão meridional, ao largo do litoral do atual Estado de Santa Catarina, e a região que viria fazer parte do Rio Grande do Sul pertencia aos espanhóis. Portugal, por sua vez, sempre procurou estabelecer como sua real fronteira, como limite extremo de seu império na América do Sul, não uma linha abstrata, mas sim a margem esquerda do Rio da Prata. Todos os conflitos entre o Brasil e seus vizinhos do Prata foram decorrentes dessas duas visões antagônicas sobre quais eram os marcos verdadeiros que os separavam.

O Rio Grande do Sul foi, desde o início, uma "fronteira quente", isto é, local de disputa militar, de guerras e de arranjos diplomáticos, área conflituosa que se estendeu 
dos finais do século XVII até o XIX, quer dizer, por quase dois séculos. O estado do Rio Grande do Sul, segundo Dacanal (1992), desempenhou duas funções importantes desde o início de sua ocupação. A primeira foi a de ser um local estratégico que garantia a presença portuguesa junto às áreas de colonização espanhola. A segunda, e não menos importante, foi a de fornecer alimentos e outros bens para as demais regiões do País.

\section{Ocupação e colonização}

A história da ocupação no Rio Grande do Sul começou muito antes da chegada dos portugueses àquele território. A região era vista como "terra de ninguém” e era povoada por índios. Apenas alguns aventureiros em busca de escravos se arriscavam a adentrar naquele território de difícil acesso. Zattera (1995) explica que os índios estavam subdivididos em tribos espalhadas pelo Estado. No início, havia o grupo jê, ramo dos tapuias, que se localizava no norte e nordeste. Desse grupo se derivavam os guaianás, subdivididos em ibiraiara, caaguá, arachã, carijó, tape e, mais adiante, os caigangues. Outro grupo de indígenas encontrado no Rio Grande do Sul foi o dos mbaias, que se subdividia em seis nações: charrua, minuano, guenoa, yaro, mboane e chaná, instalados mais ao sul e sudeste.

Em 1626, depois de atacados pelos paulistas em suas reduções no Paraguai, os jesuítas instalaram-se no território que, atualmente, compreende o Rio Grande do Sul e fundaram a Redução de San Nicolas, na chamada Zona do Tape, reunindo inúmeras tribos guaranis. Em 1641, depois de combatidos e expulsos, os jesuítas levaram consigo a maioria dos índios catequizados, deixando, no entanto, parte do gado que criavam. Sem dono, esse gado tornou-se selvagem e bravio, e formou-se uma grande reserva no espaço conhecido 
como Vacarias Del Mar. A partir desse momento, Zattera (1995) conta que esse gado se tornou importante economicamente pelo aproveitamento do couro, e a prática de sua caça passou a integrar o cotidiano da população local.

Em 1682, os padres jesuítas retornaram ao Rio Grande do Sul e fundaram, na região dos estados do Paraná e Rio Grande do Sul, na Argentina e no Paraguai, as missões jesuítas, onde grande número de índios guaranis, submetidos pelos religiosos, foi convertido ao cristianismo. Para alimentar tantos índios, os jesuítas utilizaram o gado criado nas pradarias gaúchas, aproveitando o clima e a vegetação favoráveis. Para livrar-se dos constantes ataques de paulistas e tropas em busca de índios e gado, os jesuítas resolveram concentrar os índios convertidos, que não eram poucos, em uma região mais segura, situada a noroeste do estado do Rio Grande do Sul, e fundaram os Sete Povos das Missões (1687). A base econômica era assentada na criação de gado com a extração do couro, mas os missionários dos Sete Povos se conscientizaram da importância da produção de ervamate usada pelos índios e, posteriormente, pelos padres.

Em 1750, o Tratado de Madrid ${ }^{1}$ entre Portugal e Espanha estabeleceu que a região das missões fosse administrada por Portugal, e, por maior que tivessem sido os esforços dos jesuítas, as missões foram desmanteladas. Apesar disso, deixaram um legado que, sem dúvida nenhuma, veio a influenciar a história dessa região: os grandes rebanhos de bovinos e cavalos criados soltos nas pradarias gaúchas (idem).

A presença do gado foi o principal motivo para a ocupação e fixação de portugueses em solo gaúcho. A Coroa garantia aos imigrantes a propriedade de um pequeno terreno,

1 O Tratado de Madrid, assinado em 1750 entre Portugal e Espanha, dispunha que as missões passariam ao domínio português, ficando a Colônia de Sacramento com a Coroa espanhola, não chegando, contudo, a efetivar essa troca. 
mas não seu sustento. Assim, somente em 1770 uma leva de imigrantes açorianos chegou à província para povoar a região das missões. Por causa das dificuldades de transporte, esse grupo se fixou na área onde hoje está a cidade de Porto Alegre. Praticavam a agricultura de pequena propriedade e tinham uma economia voltada para a pecuária.

Como descreve Bandeira (1995), a partir do século XIX, o governo brasileiro passou a incentivar a vinda de imigrantes europeus para o Brasil com a intenção de formar uma camada social de homens livres com habilitação profissional. Como essa ideia foi rejeitada por grande parte dos senhores de terras e escravos do norte do País, o governo direcionou os imigrantes para os estados do sul.

Os primeiros imigrantes que chegaram à província foram os alemães, em 1824, que, situados na região do atual município de São Leopoldo, em pouco tempo começaram a transformar o lugar.

Medina(1997) relata que os primeiros colonos alemães que se instalaram no Rio Grande do Sul viajaram no navio Anna Luise, partindode Hamburgoem 5 deabril de 1824 edesembarcando no Rio de Janeiro em 4 de junho do mesmo ano. A bordo do bergantim São Joaquim Protector, 38 imigrantes rumaram para Porto Alegree, em 25 de julho de 1824, começaram a instalar-se às margens do Rio dos Sinos, na antiga Real Feitoria de Linho Cânhamo, fundando a colônia de São Leopoldo. Consta que até 1825 um total de 1.027 imigrantes chegou à colônia.

$\mathrm{O}$ autor também destaca que os colonos que vieram para o Rio Grande do Sul ainda não tinham sido afetados pelo capitalismo industrial e, ao chegarem à nova terra - no caso a colônia de São Leopoldo -, encontraram toda base necessária para trabalhar, uma vez que eram em grande parte camponeses e a região só podia oferecer terras para plantio. Para os que saíram da Alemanha expulsos do meio rural por causa do avanço do capitalismo, a nova terra prometia grandes conquistas e um futuro promissor. 
Já em 1848, os imigrantes têm um novo perfil: são, em grande parte, artesãos e assalariados urbanos ou rurais, expulsos da terra-mãe pela crise que acompanhou a era das revoluções na Europa (Hobsbawm, 1996). A partir daí, começaram a chegar ao Rio Grande do Sul exilados políticos, socialdemocratas e anarquistas alemães.

A colônia cresceu rapidamente. Vinte anos após sua fundação, já se emancipava de Porto Alegre e tornou-se líder de sua região. Hoje, compreende-se o bom desenvolvimento dessa colônia a partir de sua localização geográfica. Localizada às margens do Rio dos Sinos, havia fácil comunicação fluvial com Porto Alegre e cidades como Pelotas e Rio Grande. As áreas planas e férteis para o plantio também facilitaram o bom desenvolvimento.

A partir da colônia de São Leopoldo, outras colônias alemãs começaram a se formar a sua volta. Surgiram os núcleos de Novo Hamburgo, Campo Bom, Sinos, Taquari, Sapiranga, São Sebastião do Caí e Jacuí. Até a Segunda Guerra Mundial, o Rio Grande do Sul tornou-se a segunda pátria para alemães de todas as classes sociais, e estabeleceu-se um fluxo migratório constante da Alemanha para a região.

Após o fim da escravidão em 1888, muitas famílias alemãs no Rio Grande do Sul continuaram utilizando mão de obra negra. Como a maioria dos empregados era "cria da casa", muitos negros acabaram por adotar o sobrenome alemão dos patrões e passaram a considerar-se alemães também, o que reforça a ideia de que identidade não é apenas uma questão de cor de pele nem de nascimento (Medina, 1997).

Nesse período, muitos fatos curiosos ocorreram envolvendo alemães e a população nativa nas áreas onde se localizavam as colônias. Lendas, misticismo, rivalidades pessoais, brigas por causa da crença religiosa: os alemães sempre fizeram questão de demarcar seu território com a força das particularidades de sua cultura. Ainda que estivessem vivendo em outro país e tendo contato com outras 
culturas, a cultura germânica sempre falava mais alto aos ouvidos dos imigrantes, que perpetuavam suas tradições transmitindo-as às novas gerações.

A partir de 1875 , começaram a chegar os imigrantes italianos, mas, como a região da capital já estava povoada pelos alemães, foram se instalar na região das serras. Aos poucos, formou-se um eixo básico de industrialização no estado ligando a capital e a cidade de Caxias do Sul, constituindo um intercâmbio entre alemães e italianos. A vinda dos imigrantes italianos para o Brasil está ligada ao processo de substituição de mão de obra e à política de imigração e colonização do governo imperial, que pretendia "branquear" a população brasileira: "a superioridade da população branca”, segundo a ideologia dominante, garantiria uma produção maior e poderia evitar, em longo prazo, o surgimento de um "império negro" no Brasil, o qual determinaria o fracasso nacional (Bandeira, 1995).

\section{Atividade econômica}

As missões jesuítas e a formação das estâncias de lagunenses e vicentinos - paulistas que se deslocavam do norte-foram responsáveis pela introdução da pecuária no Rio Grande do Sul. A criação de estâncias correspondeu ao abandono das atividades predatórias feitas por gente selvagem do campo, os primeiros gaúchos, que abatia indiscriminadamente os animais apenas para extrair-lhes o couro e vendê-lo aos contrabandistas (Azevedo, 1958). A agricultura, nesses primeiros tempos, confinava-se ao plantio da erva-mate, herança dos hábitos dos índios guaranis.

No início do século XVIII, com a descoberta das lavras de ouro e de diamante em Minas Gerais e o elevado preço dos alimentos nas regiões de garimpo, a pecuária virou uma atividade altamente rentável. Com a indústria extrativista 
esparramando-se pelo Brasil central, formou-se o primeiro mercado interno significativo no Brasil colônia, ao qual as estâncias gaúchas iriam atrelar-se, sendo essa uma das históricas razões econômicas da tensão entre o separatismo e o nacionalismo, vigentes até hoje no Estado.

No final do século XVIII, com a implantação das charqueadas na região de Pelotas e do Rio Jacuí, um mercado bem mais vasto se abriu, pois, com a nova técnica da conservação de carnes, foi possível superar a exportação do gado em pé. Era possível ambicionar atingir, além do centro e do nordeste do Brasil, até os consumidores do mar do Caribee dos estados sulistas dos Estados Unidos, visto que o charque era a alimentação básica dos escravos. Ironicamente, o alimento dos escravos era pago com escravos. Para Azevedo (1958), a chegada de levas deles ao território do Rio Grande doSul resultou na expansão da indústria das carnes manufaturadas e salgadas, que se multiplicaram por Pelotas e beiras da Lagoa dos Patos e margens do Rio Jacuí.

Com a vinda dos açorianos, desembarcados em 1752, a agricultura tomou um novo impulso com as plantações de trigo ao redor da cidade de Rio Grande, expandindo-se para outras áreas até ser destruída, por volta de 1820, pela praga da ferrugem e pela ausência de um apoio governamental. Os açorianos tornaram-se então pecuaristas e charqueadores.

A partir da produção colonial alemã, já em 1830, Porto Alegre, com aproximadamente 12 mil habitantes, começava a enriquecer e ensaiava sua futura vocação comercial.

A organização social gaúcha era bastante rígida. No topo encontravam-se os grandes fazendeiros e os ricos charqueadores, cabendo aos fazendeiros a hegemonia regional. Os comerciantes mais abastados tinham uma posição de destaque e eram, em boa parte, portugueses. Era importante também o número de médios e pequenos comerciantes. Os grandes polos comerciais da província eram Porto Alegre, Rio Grande, Pelotas e Rio Pardo. 
A agricultura e a criação mais diversificada de suínos e aves só se estabeleceram mais tarde com as colônias alemãs e italianas, entre 1824 e 1875, que trouxeram as técnicas industriais que permitiram lançar os fundamentos da pequena indústria do curtume e da metalurgia.

A partir de 1870, a vida econômica e social da província se transformou progressivamente de acordo com a chegada de novos imigrantes europeus e, consequentemente, de novos hábitos e novos conceitos. No aspecto econômico, um novo cultivo, o arroz, foi introduzido. A soja, nesse período, atingiu o mercado internacional, e, graças ao artesanato realizado pelos europeus, nasceu a atividade industrial que se desenvolveu em um ritmo crescente. Na região da colonização italiana, destacaram-se os setores mecânico, metalúrgico e calçadista.

No início do século XIX, a produção de trigo e a agricultura cederam lugar à pecuária como base da riqueza social. Muitos dos antigos agricultores transformaram-se em fazendeiros com a organização das charqueadas. Em razão das grandes secas nordestinas, o Rio Grande do Sul transformara-se no principal centro brasileiro produtor de charque. Na sociedade sulina de então, a vida urbana desenvolvera-se relativamente (Maestri, 2001a).

A pecuária de corte tomou novo impulso com a criação dos frigoríficos estrangeiros, da Armour e da Swift, em 1917, tornando possível exportar carnes enlatadas e refrigeradas para o centrodoPaís. Segundo Azevedo(1958), o sucesso daeconomia colonial deve-se sobretudoà distribuição de terras feitas entreos colonos, formando não apenas um dinâmico centro produtivo policultural, mas também um crescente mercado consumidor.

O crescimento industrial não significou o abandono da agricultura, e, ainda hoje, o estado do Rio Grande do Sul, com o Paraná, é um dos grandes responsáveis pela produção nacional de grãos. De um estado que se encontrava às margens da economia do País, o Rio Grande do Sul transformouse em uma das bases dessa economia. 


\section{O gaúcho}

Segundo Love (1975), a palavra "gaúcho", o homem livre dos campos, foi aplicada inicialmente para definir um tipo humano arredio, o nômade do pampa, muitas vezes um desertor desobediente da lei e da ordem, que cavalgava sem rumo em uma área vastíssima sempre atrás de gado amansado ou chucro e de cavalos. Gente de laço e de doma, sua cultura derivou de um amálgama entre os hábitos indígenas e europeus, resultando em um caldeamento étnico muito próprio.

Darcy Ribeiro (1995), em O povo brasileiro: a formação eo sentido do Brasil, traz um capítulo especial sobre a Região do Sul do Brasil: "Brasis sulinos: gaúchos, matutos e gringos". O autor destaca que esta é uma área cultural complexa e singular e que sua característica básica, em comparação com as outras áreas culturais brasileiras, é sua heterogeneidade cultural. A configuração histórico-cultural do estado do Rio Grande do Sul é constituída por três elementos: os lavradores matutos (de origem principalmente açoriana), os representantes atuais dos antigos gaúchos e a formação gringo-brasileira dos descendentes de imigrantes europeus.

Segundo o autor, a configuração histórico-cultural dos matutos é constituída de populações transladadas dos Açores no século XVIII, pelo governo português. O objetivo dessa colonização era implementar um núcleo de ocupação lusitana permanente para justificar a apropriação da área perante o governo espanhol. Esses matutos viviam como lavradores, estabelecendo no Rio Grande do Sul o mesmo modo de vida que tinham nos Açores, uma agricultura exercida de modo arcaico.

Os gaúchos originam-se da transfiguração étnica das populações mestiças de varões espanhóis e lusitanos com mulheres guaranis. Eram homens fortes, caçadores, que tinham no gado selvagem sua subsistência e a base econômica de sua sociedade. 
A terceira configuração histórico-cultural do Rio Grande do Sul é constituída pelos povos de origem germânica, italiana, polonesa, japonesa, libanesa e várias outras, introduzidos como imigrantes no século XIX. Viviam em colônias, propriedades familiares em que cultivam grãos e cereais, criavam animais e das quais tiravam seu sustento. $\mathrm{O}$ contato entre essas três configurações culturais foi inevitável. A coexistência desses três complexos culturais operou ativamente no sentido de homogeneizá-los, difundindo traços e costumes de um ou outro. Essa interação é definida por Ribeiro (1995, p.409) da seguinte forma:

A distância que medeia entre os respectivos patrimônios culturaise, sobretudo, entre seus sistemas de produção agrícola-a lavoura de modelo arcaico dos matutos, o pastoreio gaúcho ea pequena propriedade explorada intensivamente pelos colonos gringos-funciona, porém, como fixadora de suas diferenças. Mesmo em face dos efeitos homogeneizadores da modernização decorrentes daindustrializaçãoe da urbanização, cada um destes complexos tende a reagir de modo próprio, integrando-se com ritmos e modos diferenciados nas novas formas de produçãoe de vida, dando lugar a estilos distintos de participação na comunidade nacional.

Para o autor, é essa a singularidade do povo sul-riograndense de hoje. A complexidade de sua origem históricocultural torna-o um grupo diferente dos demais brasileiros.

\section{O tradicionalismo gaúcho}

O século XX foi o período das transformações. Novos inventos passaram a integrar a vida das pessoas, mudando hábitos e conceitos. A televisão, presente em praticamente todas as residências, permite que informações sejam transmitidas e globalizadas. O mundo passa a ser visto com outros olhos, e nem mesmooscostumesetradiçõesficaramimunesaessefenômeno. 
Essas transformações também afetaram a sociedade sul-rio-grandense. No entanto, em meados do século XX, começou a aparecer, em alguns gaúchos, um sentimento novo: a sua diferença em relação ao mundo. Vera Stedile Zattera (1995, p.153), historiadora, gaúcha de Caxias do Sul, descreve esse sentimento:

É a nossa cidadania, é nossa raça, tão mesclada, mas tão clara. É nossa consciência de sermos elementos batalhadores, especiais, que grita. É hora de mostrarmos ao mundo do que nós, gaúchos, somos capazes, do que gostamos, quais são nossas músicas, quais são nossos hábitos, quais são nossas habilidades.

O gaúcho é resultado da miscigenação de portugueses, espanhóis, africanos, alemães, italianos com o índio da terra. Mas esse grupo não sabia como mostrar suas raízes históricas, seus costumes nativos, sua maneira de ser. Foram criados então os centros de tradições gaúchas (CTG), com a finalidade de mostrar e perpetuar suas manifestações com a maior precisão possível, por meio de sua música e sua sociabilidade. Nos CTG, estudam-se as danças, as poesias, as falas do gaúcho original, seus hábitos e sua história. Seu objetivo é mostrar esses detalhes ao público nacional e internacional. $\mathrm{O}$ Instituto Gaúcho de Tradiçãoe Folclore(IGTF) preocupa-se em nortear os estudos e as pesquisas sobre os usos e costumes gaúchos. O Movimento Tradicionalista Gaúcho lidera hoje mais de mil CTG somente no Rio Grande do Sul e outras centenas deles espalhados por todo o Brasil e pelo mundo. ${ }^{2}$

O resultado de tudo isso pode ser constatado nos dias de hoje: o gaúcho aprendeu a cultuar o Rio Grande do Sul, e comemora-se no dia 20 de setembro o Dia do Gaúcho, um dia para lembrar-se de sua história e do tradicionalismo.

2 Segundo a Confederação Brasileira de Tradição Gaúcha (CBTG), em 2009 foi inaugurado o $12^{\circ}$ CTG fora do Brasil. 
Em todo o lugar, pode ser percebido o respeito por suas tradições. Os clubes sociais e fábricas incentivam seus grupos folclóricos a dançar e mostrar as roupas típicas. Os restaurantes servem o churrasco com músicas e danças típicas ao vivo. Nas escolas, é ensinado o respeito ao território, a sua história e a suas tradições. Rádios e emissoras de TV transmitem músicas e programas sobre a vida gaúcha, suas origens e seus costumes, com o objetivo de divulgar a cultura aos mais jovens. É muito comum ver o gaúcho usando bombachas, sua indumentária típica, não somente em datas comemorativas, mas também em seu dia a dia.

\section{Enfrentamentos ideológicos, políticos e partidários}

Ser uma fronteira "quente", permanentemente disputada, deu uma feição belicosa aos confrontos políticos e ideológicos do Rio Grande do Sul. Pelo fato de os limites do estado serem imprecisos, emaranhados na vastidão das planícies, as facções emluta eram obrigadas a procurar abrigoou recursosem regiões muito além da fronteira. Era difícil para uma força policiar um território tão amplo, permitindo com isso que as guerras tivessem larga duração, como se deu com a Revolução Farroupilha, liderada por Bento Gonçalves, que, arrastando-se por dezanos, de 1835 a 1845, foi a mais longa das guerras civis brasileiras.

Para Boeira et al. (1980), a constância dos combates fez que a exigência da politização da população fosse sempre muito intensa, o que acirrou ainda mais os enfrentamentos partidários, criou uma hostilidade entre os partidos, quase sempre polarizados em duas correntes pouco dispostas à conciliação, e gerou um clima propício à guerra civil.

No Quadro 1, pode-se verificar a cronologia dos enfrentamentos ideológicos, políticos e partidários nos séculos XIX e XX, no Rio Grande do Sul, segundo Boeira et al. (1980). 


\section{Quadro 1 - Cronologia dos enfrentamentos ocorridos nos} século XIX e XX

\begin{tabular}{|c|c|c|c|}
\hline DATAS & \multicolumn{3}{|l|}{ ACONTECIMENTOS } \\
\hline \multirow[t]{2}{*}{$1835-1845$} & \multicolumn{3}{|l|}{ Revolução Farroupilha } \\
\hline & $\begin{array}{l}\text { Farrapos } \\
\text { (republicanos, separatistas) } \\
\text { Líder: Bento Gonçalves }\end{array}$ & $\mathrm{X}$ & \begin{tabular}{|l} 
Imperiais \\
(monarquistas, \\
centralistas) \\
Governo da regência \\
\end{tabular} \\
\hline \multirow[t]{2}{*}{$1846-1889$} & \multicolumn{3}{|l|}{ Bipartidarismo } \\
\hline & $\begin{array}{l}\text { Monarquistas liberais } \\
\text { (maior autonomia da } \\
\text { província) } \\
\text { Líder: Gaspar Silveira } \\
\text { Martins }\end{array}$ & $\mathrm{X}$ & $\begin{array}{l}\text { Monarquistas } \\
\text { conservadores } \\
\text { (a favor da centralização } \\
\text { da corte) }\end{array}$ \\
\hline \multirow[t]{2}{*}{$1893-1895$} & \multicolumn{3}{|l|}{ Revolução Federalista } \\
\hline & $\begin{array}{l}\text { Republicanos (pica-paus) } \\
\text { (ditadura positivista, aliados } \\
\text { ao presidencialismo) } \\
\text { Líder: Júlio de Castilhos }\end{array}$ & $\mathrm{X}$ & $\begin{array}{l}\text { Federalistas (maragatos) } \\
\text { (ex-monarquistas, } \\
\text { parlamentaristas) } \\
\text { Líder: Gaspar Silveira } \\
\text { Martins } \\
\end{array}$ \\
\hline \multirow[t]{2}{*}{1923} & \multicolumn{3}{|l|}{ Revolução de 1923} \\
\hline & $\begin{array}{l}\text { Borgistas (chimangos) } \\
\text { (continuidade da ditadura) } \\
\text { Líder: Borges de Medeiros }\end{array}$ & $\mathrm{X}$ & $\begin{array}{l}\text { Assisistas (maragatos) } \\
\text { (fim do continuísmo } \\
\text { borgista) } \\
\text { Líder: Assis Brasil } \\
\end{array}$ \\
\hline \multirow[t]{2}{*}{$1945-1964$} & \multicolumn{3}{|c|}{ Enfrentamento ideológico-partidário } \\
\hline & $\begin{array}{l}\text { Trabalhistas } \\
\text { (campanha trabalhista } \\
\text { pró-getulista), Partido } \\
\text { Trabalhista Brasileiro (PTB) } \\
\text { Líder: Alberto Pasqualini/ } \\
\text { Leonel Brizola }\end{array}$ & $\mathrm{X}$ & $\begin{array}{l}\text { Conservadores } \\
\text { (antitrabalhistas), União } \\
\text { Democrática Nacional } \\
\text { (UDN), Partido } \\
\text { Libertador (PL) } \\
\text { Líder: Ildo Meneghetti }\end{array}$ \\
\hline $1964-1985$ & $\begin{array}{l}\text { Peemedebistas } \\
\text { (contra o regime militar) } \\
\text { Líder: Pedro Simon }\end{array}$ & $\mathrm{X}$ & $\begin{array}{l}\text { Arenistas } \\
\text { (sustentação civil do } \\
\text { regime) } \\
\text { Líder: diversos }\end{array}$ \\
\hline
\end{tabular}





\section{2 \\ ETNICIDADE E IDENTIDADE ÉTNICA}

São inúmeros os estudos de etnicidade relacionados a grupos humanos diferentes desenvolvidos pelas Ciências Sociais. Não é o objetivo fazer aqui uma análise exaustiva ou mesmo um histórico do uso do conceito e de como os trabalhos foram e são direcionados. $\mathrm{O}$ intuito é somente apresentar um panorama dessa problemática para contextualizar como se construiu o conceito de etnicidade como pressuposto deste estudo, com a finalidade de entender o ideal separatista presente em alguns grupos de gaúchos.

Quando se pensa na possibilidade de identificação étnica, corre-se o risco de buscar grupos culturais fechados e estáticos, de buscar uma filiação, um nome, um recorte geográfico. No entanto, a questão não é tão simples. Mesmo que os registros históricos fornecessem as pistas necessárias para esse tipo de identificação, ou de qualquer outra natureza de fonte acadêmica, esses dados não teriam, por si sós, autoridade para desenhar um mapa desse percurso, na medida em que os grupos humanos e a construção da identidade étnica são extremamente dinâmicos e flexíveis. Dessa maneira, a concepção de etnicidade está além da definição de culturas específicas e, portanto, é composta de mecanismos 
de diferenciação e identificação que são acionados conforme os interesses dos indivíduos em questão, assim como o momento histórico no qual estão inseridos.

Os conceitos de grupo étnico, identidade étnica e etnicidade têm uma complexa trajetória teórica nas Ciências Sociais. As dificuldades podem ser constatadas nas muitas coletâneas, em textos e estudos de caso publicados desde a década de 1970. A unidade concreta de análise - o grupo étnico - tem sido definida por diferentes combinações de características que vão da cultura comum à identidade étnica simbolicamente construída. A revisão do conceito-realizada com base em trabalhos de autores como Abner Cohen (1969) e Frederick Barth (1969), por exemplo - resultou na incorporação das noções de identidade étnica e etnicidade, com críticas contundentes à concepção tradicional que concebia o grupo étnico como unidade cultural distinta, separada. Sobre a complexidade de se estudar o conceito de etnicidade, Poutignat \& Streiff-Fenart (1998, p.117) afirmam o seguinte:

Estudar a etnicidade consiste, então, em inventariar o repertório das identidades disponíveis em uma situação pluriétnica dada e descrever o campo de saliência dessas identidades nas diversas situações de contato. A análise situacional da etnicidade liga-se ao estudo da produção e da utilização das marcas, por meio das quais os membros das sociedades pluriétnicas identificam-see diferenciam-se, e ao estudo das escolhas táticas e dos estratagemas que acionam para se safarem do jogo das relações étnicas. Entre essas táticas figuram especialmente a alternância de identidades (identity switching), o domínio da impressão e os processos de alter-casting que permitem atribuir um papel étnico ao outro.

Segundo Poutignat \& Streiff-Fenart (1998), nas diversas formas de conceituação, a etnicidade pôde ser definida como caráter ou qualidade do grupo étnico (Glazer \& Moynihan, 1975), como fenômeno situacional (Williams, 1989), como o 
sentimento de formar um povo (Gordon, 1964), como o relacionamento entre grupos que se consideram e são considerados culturalmente distintos(Eriksen, 1991) ou como fenômeno de natureza política ou econômica, remetendo a grupos de pessoas unidas em torno de interesses comuns (Cohen, 1974).

As contribuições desses e de outros autores permitem avançar no sentido de considerar as especificidades de uma identidade propriamente étnica. Lapierre (1998)e Poutignat \& Streiff-Fenart (1998) propõem que a identidade étnica é uma forma de organização social cujo sistema de categorização fundamenta-se em uma origem suposta. A questão referenteà origem é recuperada da contribuição weberiana sobre os grupos étnicos, para a qual a crença subjetiva na origem comum constitui um laço característico da etnicidade.

A partir dos estudos de Barth (1998), torna-se possível definir grupo étnico como uma forma de organização social, que expressa uma identidade diferencial nas relações com outros grupos e com a sociedade mais ampla. A identidade étnica é utilizada como forma de estabelecer os limites do grupo e de reforçar sua solidariedade. Nessa concepção, a continuidade dos grupos étnicos não é explicada em termos de manutenção de sua cultura tradicional, mas depende da manutenção dos limites do grupo, da contínua dicotomização entre membros e não membros (nós/eles). Os traços culturais que demarcam os limites do grupo podem mudar, e a cultura pode ser objeto de transformações, sem que isso implique o esvaziamento da solidariedade étnica. ${ }^{1}$ Poutignat \& Streiff-Fenart (1998, p.141) concordam com a definição de Barth e completam:

1 Essa perspectiva aproxima-se da proposta de Hall (1999, p.49-50), que concebe a identidade como um conjunto de representações culturais, construído em situações específicas, um "modo de construir sentidos que influencia e organiza tanto nossas ações quanto a concepção que temos de nós mesmos". 
Há que convir com Barth, que a etnicidade é uma forma de organização social, baseada na atribuição categorial que classifica as pessoas em função de sua origem suposta, que se acha validada na interação social pela ativação de signos culturais socialmente diferenciadores. Esta definição mínima é suficiente para circunscrever o campo de pesquisa designado pelo conceito de etnicidade: aquele dos estudos dos processos variáveis e nunca terminados pelos quais os atores identificam-se e são identificados pelos outros na base de dicotomizações Nós/Eles, estabelecidas a partir de traços culturais que se supõe derivados de uma origem comum e realçados nas interações raciais.

Frederich Barth (1998) afirma que os indivíduos têm de estar conscientes de sua identidade étnica e com uma atuação dinâmica a seu favor. Isso significa que cada indivíduo, dentro de um determinado contexto histórico e geográfico, contribui para a etnicidade de seu grupo, servindo como ator da trama cultural. Nem sempre as pessoas de um grupo participam da formação de sua identidade étnica conscientemente. Muito do que aprendem a respeito de sua identidade étnicaéinconsciente e faz parte de sua educação desde seu nascimento.

A etnicidade é uma entidade relacional, pois está sempre em construção, de um modo predominantemente contrastivo, o que significa que é construída no contexto de relações e conflitos intergrupais. A forma contrastiva que caracteriza a natureza do grupo étnico resulta de um processo de confronto e diferenciação. Tudo isso acentua a natureza dinâmica da identidade étnica que se constrói no jogo de confrontos, oposições, resistências, como também, e sobretudo, no jogo da dominação e submissão. Barth também ressalta que o caráter contraditório da relação entre grupos étnicos aparece mais claramente quando se trata de minorias em suas relações de sujeição para com as sociedades que as envolvem.

Sendo assim, identidade étnica implica cultura. Cultura faz parte da identidade étnica de um grupo, e tal identidade transcende os aspectos culturais deste, porqueé influenciado 
por aspectos que estão fora da dimensão do grupo. Cultura vem a ser o aspecto de um grupo que permite que seus integrantes se sintam unidos entre si.

Tanto cultura como etnicidade são termos que implicam obrigatoriamente uma dinâmica. Isso significa que um grupo não permanecerá com seus aspectos culturais indeterminadamente, mas que essas qualidades serão modificadas com o passar do tempo, de acordo com o que o novo contexto contribuirá para a comunidade. Uma cultura necessariamente vai se transformar com o passar do tempo em consequência de fatores externos ou internos. Por isso, sua identidadeétnica estará constantemente sendo colocada em questão.

De acordo com Barth (1998), grupos não podem ser ordenados como um todo homogêneo. Culturas estão sempre em movimento, contêm contradições e são incoerentes. Juntando a problemática das variações que cada cultura traz consigo e sua implicação no estudo da identidade étnica de um grupo, Barth afirma que a cultura pode ser utilizada para manter a diferenciação entre grupos étnicos próximos geograficamente, por meio de processos internos que possam acentuar as diferenças entre eles.

Seguindo a reflexão de Barth, Poutignat \& Streiff-Fenart (1998, p.129) explicam a relação entre etnicidade e cultura:

Em razão dessa disjunção entre cultura e etnicidade, geralmente se admite que o grau de enraizamento das identidades étnicas nas realidades culturais anteriores é altamente variável, e que toda cultura "étnica" é, em certa medida, "remendo". A etnicidade não é vazia de conteúdo cultural [...] mas ela nunca é também a simples expressão de uma cultura já pronta. Ela implica sempre um processo de seleção de traços culturais dos quais os atores se apoderam para transformá-los em critérios de consignação ou de identificação com um grupo étnico. Concorda-se igualmente em reconhecer que os traços ou os valores aos quais pessoas escolhem para prender suas identidades não são necessariamente os mais importantes, os que possuem 


\begin{abstract}
"objetivamente" o maior poder de demarcação [...] Uma vez selecionados e dotados de valor emblemático, determinados traços culturais são vistos como a propriedade do grupo no duplo sentido de atributo substancial e de posse [...] e funcionam como sinais sobre os quais se funda o contraste entre Nós e Eles.
\end{abstract}

Nessa perspectiva, a concepção de cultura éentendida nas suas dimensões antropológica e sociológica, não restrita aos aspectos puramente étnico/raciais, mas articulada a outras categorias como nação, classe, gênero, religiosidade. A cultura compreendida a partir desse ponto de vista articula essa diversidade de relações produzidas no cotidiano, combina seus significados simbólicos, constituindo o que Geertz (1978) denominou de teia de significados. Uma dinâmica que rompe com a visão de cultura no singular, remetendo para uma concepção de que a cultura é mais bem compreendida se for inserida dentro de universos múltiplos, coexistindoeenfrentando esses movimentos permanentementeem processo de metamorfose.

A ideia de etnia deve ser introduzida em contextos sociais, políticos e econômicos, a fim de situar e entender os fenômenos étnicos contemporâneos, tornando expressões como movimentos étnicos, grupos étnicos, guerra entre etnias, etnia cigana, negra, afro-americana, indígena, correntes em nosso cotidiano.

A etimologia do termo etnia situa-se na expressão grega ethnós, que significa povo. Quanto ao termo étnico, procede do latiméthnicus. A partir do século XIX, o termo passou a ser associado à terminologia raça como forma de distinguir as diferentes populações humanas. Vários estudiosos propuseram, inclusive, a substituição do termo raça pelo de etnia, embora essa proposição não tenha alterado as concepções hierarquizadoras já consagradas pelo conceito de raça na distinção dos grupos humanos. Essa perspectiva ajuda a formular uma possível diferenciação entre estes dois conceitos, utilizando os processos históricos distintos que os forjaram. 
O conceito de raça deriva de um contexto impositivo de distinções - classificações de características físicas, biológicas - por parte de grupos dominantes no período colonial. Já o termo etnia envolve a descrição daquelas características herdadas culturalmente que fundamentam a existência de um determinado grupo humano em um passado ancestral comum (Pujadas, 1993). Nesse sentido, a identidade étnica passa a ser o acúmulo dessas heranças culturais que permitem significar distinções perante outros grupos sociais/étnicos.

No Brasil, por exemplo, o reconhecimento de diferenças étnicas e expressões que podem ser chamadas de etnicidades - manifestadas por meio de identidades específicas ocorre nas populações indígena e negra, até de modo mais explícito, porque esses grupos sofrem mais, objetivamente, processos de discriminação e preconceito. No entanto, aparecem também entre descendentes de imigrantes, além das outras identidades vinculadas às diversidades regionais que assumem caráter étnico na medida em que se apoiam em ideais separatistas que, nos últimos anos, atingiram ressonância global.

Dentro dessa problemática, observa-se que não são as diferenças culturais que acentuam as diferenças dos gaúchos em relação aos demais brasileiros, mas sim sua etnicidade, que é legitimada por meio de aspectos históricos, sociais e políticos que se referem ao Rio Grande do Sul e aos demais estados brasileiros. A identidade étnica de um grupo transcende seus aspectos culturais, não envolvendo somente aspectos internos dessa cultura, mas sendo particularmente envolvida pelas interações do grupo com o mundo a seu redor.

Não se deve falar de cultura no singular, mas em culturas, no plural. Não se deve fazer uma classificação de culturas, principalmente porque as práticas e as instituições variam de formação social para formação social. 
A diversidade das culturas existentes acompanha a variedade da história humana, expressa possibilidades de vida social organizada e registra graus e formas diferentes de domínio humano sobre a natureza. Dessa forma, a cultura gaúcha - se é que se pode referir assim às expressões culturais daquele grupo social - é apenas uma das culturas presentes no Brasil, nãoé melhor nem pior, apenas diferente e singular no contexto nacional. 


\section{3 \\ O SEPARATISMO No Rio Grande do Sul}

\section{Federação versus confederação}

O termo federação remonta ao latim no qual o signo foederis transmite a ideia de união, pacto. Seu uso, no que se refere a atributo ou forma de Estado, só é possível a partir do exemplo norte-americano que, após a independência de suas treze colônias, originou o Estado federal no século XVIII.

Ao declararem-se independentes, as treze colônias se transformaram em treze estados livres e autônomos, regidos cada qual por suas próprias leis, podendo decidir, segundo seus próprios critérios, todos os assuntos de seu interesse e resolver os problemas com seus próprios meios. Isso só foi possível por causa da particularidade do regime de colonização de povoamento nas colônias do norte, do qual se originaram a estrutura de classes, a luta pela independência e o projeto de desenvolvimento, levando os norte-americanos à concepção de um sistema de organização de seu Estado nacional totalmente inovador e consonante com os anseios do liberalismo. Apesar de tudo isso, por questões de segurança e para melhor enfrentar os problemas comuns, uma união fazia-se necessária. 
Segundo Molon (1994), a solução para essa questão foi apresentada por Benjamin Franklin em 1754, mas só ganhou força em 1781 quando os estados assinaram um tratado de união em forma de confederação: os Artigos de Confederação. Esses artigos não eliminaram a autonomia nem a soberania de cada estado, mas prescreviam a união perpétua entre eles, passando a designá-los Estados Unidos Reunidos em Congresso e, posteriormente, Estados Unidos da América. Todos se submeteram a uma Constituição Federal baseada na crença nos direitos naturais do indivíduo, no antiabsolutismo e na divisão entre os poderes Executivo, Legislativo e Judiciário.

Para compreender o ideal separatista presente no sul do Brasil, devem-se esclarecer as diferenças entre federação e confederação. Para Dallari(1986), a diferença básica reside nas bases jurídicas. Na confederação, os integrantes encontram-se associados por um tratado que guarda a soberania do estado participante, no qual continua respondendo por si próprio, delegando atribuições à União, só preservando os poderes que os Estados lhe conferiram. Na federação, os estados submetem-se a uma Constituição comum, restando-lhes de seus antigos poderes somente aqueles que a Carta lhes assegura.

Molon(1994) apresenta o autor AllyrioWanderley como o teórico do separatismo no Brasil. Segundo Molon, Wanderley fundamenta o separatismo em seu livro As bases do separatismo (1935), resultado do momento que o País vivia na década de 1930, período que transmite ao autor a ideia de que a derrocada financeira, a instabilidade política e a inquietação social são sintomas de um único fenômeno: a morte do Brasil.

Para Wanderley (apud Molon, 1994), cada região brasileira se encontra em diferentes graus de desenvolvimento e situações geográficas, cabendo a cada uma necessidades e recursos distintos. Para melhor satisfazer suas necessidades, o ideal, segundo o autor, é estarem separadas, uma vez que juntas não há meios de fazê-lo, pelo fato de a União adotar me- 
didas homogêneas que se tornam inúteis em algumas regiões. Para o autor, romper com a unidade é um meio de acabar com o "aparelho central de desgoverno, parasita, sanguinolento e tentacular" que trava o desenvolvimento autônomo das regiões. Grande parte do discurso do Movimento Separatista Sulino atual se baseia nos conceitos de Allyrio Wanderley.

É bem verdade que, em toda a história, o povo brasileiro aparece como coadjuvante do processo, embora os atores envolvidos falassem em seu nome e afirmassem, a todo o momento, a legitimidade de suas campanhas, assentadas sobre a vontade popular. Foi assim em todos os movimentos separatistas do século XIX. No caso da Revolução Pernambucana (1817), da Revolução Farroupilha (1835), da Sabinada (1838), todos os agentes históricos insistem em afirmar que era a vontade do povo fazer valer sua autonomia, mas escondem a intenção de uma elite agrária que visava ao poder e ao controle de determinada região.

Outros exemplos de movimentos separatistas podem ser destacados. No mundo todo, várias frentes separatistas procuram emancipar suas regiões; muitas vezes, essa luta deixa de ser pacífica e passa a ser armada, violenta. Podese destacar o movimento separatista no norte da Itália, liderado pela Liga Norte. Na Bélgica, onde flamengos e valões procuram emancipar seus Estados. No México, onde Chiapas tornou-se palco das lutas zapatistas. No Brasil, pode-se afirmar que, em praticamente todos os estados, há um movimento separatista para formar um novo país ou para tornar uma dada região um novo Estado. Entre eles, pode-se destacar o movimento separatista de São Paulo, do Nordeste Independente, da Bahia Independente e o Movimento Separatista Sulino, que pretendem emancipar seus estados e criar um novo país. Também temos movimentos emancipacionistas em diversos bairros e distritos de grandes cidades para formar um novo município, apoiados pelo Fundo de Participação dos Municípios. Movimentos por 
novos estados são encontrados em várias regiões do país, entre elas, na região do Triângulo Mineiro, no sul da Bahia, para formar o estado de Santa Cruz e na região de Itapeva (sul e sudeste de São Paulo), que pretende formar o estado de São Paulo do Sul.

\section{O Rio Grande do Sul e o Movimento Separatista Sulino contemporâneo}

O Movimento Separatista Sulino contemporâneo teve origem no estado do Rio Grande do Sul, onde se encontra em estágio mais organizado. O movimento é definido como

Uma Instituição criada com a finalidade de elaborar estudos para avaliar as possibilidades de emancipação política e administrativa dos estados do Paraná, Santa Catarina e Rio Grande do Sul, desencadeando um amplo debate na região sobre o tema de sua autonomia em relação ao Brasil como nação, através da reforma do regime federalista, com a adoção do regime confederado. ("Manifesto do povo gaúcho" in www. pampa.cjb.net $)^{1}$

O objetivo explícito no documento é criar um novo país, a República Federal do Pampa. ${ }^{2}$

As lideranças do movimento alegam que a Região Sul do Brasil sempre esteve à margem das atenções do governo federal e que toda sua história foi construída de forma independente, enfatizando a Revolução Farroupilha, a Procla-

1 As informações extraídas do site oficial do Movimento Separatista Sulino contemporâneo foram registradas durante os anos de 1999 a 2003. O endereço atual do é http://www.pampalivre.info. Acesso em agosto de 2009.

2 A instituição está registrada na cidade de Laguna, no cartório de registros de pessoas jurídicas, sob o n ${ }^{\circ} 363$, folha 186 do livro A3, e inscrita no CGC do Ministério Federal sob o n ${ }^{\circ} 80.961 .337 / 0001-0$. 
mação da Independência da República Sul-rio-grandense, em 11 de setembro de 1836, pelo coronel Antônio de Souza Neto e a Revolução Federalista. Seus integrantes justificam que a Região Sul possui uma configuração cultural diferente dos demais estados brasileiros, uma tradição e costumes arraigados desde sua origem, uma produção significativa de alimentos e que, por isso, estão condenados a "carregar" os estados brasileiros mais pobres e que sofrem de discriminação política, econômica e fiscal por parte do governo federal.

Como se tentou demonstrar anteriormente, outras intenções e discursos dos separatistas mostram a existência de um pano de fundo que, a todo o momento, remete a questões econômicas, políticas e culturais, sempre ressaltando uma pretensa "relativa superioridade" dos habitantes da Região Sul do País. Percebe-se, em vários momentos desses discursos, a utilização de conceitos filonazistas, enfatizando o forte regionalismo e o sentimento de superioridade da "raça europeia", por tratar-se de uma região colonizada principalmente por alemães e italianos, uma vez que, na Região Sul, segundo eles, a miscigenação com o negro e com o índio ocorreu em menor grau se comparado com o resto do Brasil. Para eles, o "Rio Grande do Sul nãoé e nunca foi Brasil. É uma outra nação”. ${ }^{3}$

É justamente pelo caráter histórico do Movimento Separatista Sulino que adota-se o termo "contemporâneo" como maneira de diferenciá-lo dos movimentos de autonomia do passado (Revolução Farroupilha (1835-1845) e Federalista (1893-1895))e, principalmente, porque isso demonstra que a ideia de separação e independência não é uma novidade do século XX, fazendo parte da própria história do povo gaúcho, apesar de que, no passado, a ideia de emancipação esteja ligada a outro contexto e outras motivações.

3 Carta enviada à Organização das Nações Unidas (ONU), disponível no site do Movimento pela Independência do Pampa (MIP): http:// www.pampa.cjb.net. 
Diante das várias questões levantadas em todo País perante os movimentos separatistas de caráter regional ou estadual e principalmente o Movimento Separatista Sulino contemporâneo, torna-se significativamente necessário entender as causas da criação de movimentos como esse, que busca, por meio da emancipação dos estados da Região Sul, por exemplo, criar um novo país, cindindo assim o território brasileiro.

Ainda mais, no caso particular do Movimento Separatista Sulino contemporâneo, quando se considera que ele possui como seguidores pessoas de todas as origens, de todas as classes sociais e de vários pontos do Brasil - gaúchos que vivem em outros estados e simpatizantes da causa -, a necessidade de compreendê-lo torna-se evidente, principalmente diante dos sintomas claros de crise do atual "pacto federativo", como aspecto da crise do Estado brasileiro.

Pretende-se demonstrar uma possibilidade do que foi o processo de criação do Movimento Separatista Sulino contemporâneo, interpretando os fatos históricos e construindo uma trajetória para esse movimento social, e como o conceito de identidade étnica interage nesse caso.

O Movimento Separatista Sulino contemporâneo começou a tomar forma em 1985, quando o gaúcho Irton Marx e outros separatistas escreveram o "Manifesto do Povo Gaúcho" em 7 de junho de 1985, na "República do Pampa”, como eles mesmos denominam o estado do Rio Grande do Sul. Irton Marx é um dos líderes do movimento e, em 1993, esteve em evidência nos veículos de comunicação nacionais, pelo fato de ter sido preso portando material de propaganda nazista.

O movimento possui pelo menos duas frentes de atuação, o Movimento pela Independência do Pampa (MIP), fundado em fevereiro de 1990, e o movimento O Sulé Meu País, que, em 17 de maio de 1992, se tornou uma instituição, registrada no Cartório de Registros de Pessoas Jurídicas sob 
o número 363, fls. 186 do Livro A-3, e inscrita no CGC-MF sob o número 80.961.337/0001-02, com sede na cidade de Laguna, Santa Catarina. O objetivo dessa instituição é elaborar estudos para avaliar as possibilidades de emancipação política e administrativa dos estados do Paraná, Santa Catarina e Rio Grande do Sul, com a reforma do regime federativo, adotando o regime confederado, rumo à reconstituição da antiga República Sul-rio-grandense, proclamada em 1836, durante a Revolução Farroupilha.

Ao perceberem que precisavam de apoio, os separatistas gaúchos resolveram buscar apoio nos vizinhos mais próximos, pois assim, acreditam, será mais fácil atingir seus objetivos, uma vez que alegam que Paraná e Santa Catarina sofrem da mesma discriminação por parte do governo federal que o Rio Grande do Sul. O movimento possui mais de 800 comissões municipais em cidades espalhadas pelos estados da Região Sul.

Os separatistas organizam assembleias periódicas em seus comitês e divulgam amplo material de divulgação sobre a emancipação: cartilhas, cartazes, adesivos e site na internet http://www.pampa.cjb.net (acessado durante os anos de 1999-2003). O alvo da divulgação, além das assembleias, são organizações de bairro, CTG e comitês políticos. A imprensa local, principalmente as estações de rádios, divulga os eventos e as notícias do movimento e promove entrevistas com seus integrantes.

A identidade regional gaúcha é uma das mais fortes no Brasil. Para os separatistas, essa identidade foi construída com base em seu modelo de colonização incorporado à resistência dos farrapos. Eles reforçam sua identidade a partir da referência à fisiografia e à economia regionais, afirmando que sua história sempre foi negligenciada pelo resto do País. Não se pode deixar de mencionar o papel ideológico de formação, no imaginário coletivo, de uma ideia de Rio Grande do Sul forte, poderoso. 
O objetivo deste estudo não foi o de enaltecer e tampouco desprezar esses ideais, mas oferecer ao leitor uma forma de compreendê-los. Para tanto, procura-se destacar os vários argumentos apresentados pelos separatistas para alcançar seus objetivos, refletindo a respeito da interação de processos nacionais com os processos regionais e verificando sua repercussão popular, o que será feito a seguir.

Os separatistas tentam criar um caráter de eternidade do movimento. Esse caráter aparece quando é mencionada a Revolução Farroupilha, em uma tentativa de convencer o interlocutor de que a emancipação é vontade geral e tem fundamentação histórica:

Com a Proclamação da Independência do Uruguai em 25 de Agosto de 1825, a Província Cisplatina é ferida, perdendo parte de seu território. Encabeçada pelo Cel. Bento Gonçalves da Silva, Honofre Pires e Domingos Crescêncio, entre outros heróis gaúchos, iniciou em 20 de Setembro de 1835, a Revolução Farroupilha, com a tomada do Palácio Piratini, e e expulsão do então Presidente Provincial Fernandes Braga. Como ato contínuo e consequêencia o Cel. Antônio de Souza Neto, em 11 deSetembro de 1836, proclama a Independência da República Sul-riograndense, no campo dos Meneses em Piratini, estabelecendo também ali a primeira capital do novo País. Até hoje a bandeira oficial do Rio Grande do Sul mantém em seu escudo central a inscrição REPÚBLICASUL-RIO-GRANDENSE. Em 1845, dia 28 de fevereiro, o traidor Farroupilha David Canabarro assina o tratado de Armistício, a Paz do Ponche Verde. Este tratado contudo, não desfaz o ato da Proclamação da Independência do Rio Grande do Sul, ao contrário, o mantém intacto. ("Autodeterminação-motivos históricos" in http://www.pampa.cjb.net)

[...] O Rio Grande do Sul tem história para se manter no mesmo caminho do Uruguai, qual seja, da sua total e absoluta independência, aliás, independente jáé, só se almeja restabelecer a antiga República Sul-rio-grandense... Nada Mais. O Povo será o protagonista deste episódio desde que não esteja aculturado: povo que não tem virtude, acaba por ser escravo. (idem) 
No plano econômico, o discurso da emancipação enfatiza a importância da economia gaúcha, os investimentos de capital que os próprios gaúchos ali realizam, além dos excelentes indicadores sociais. Os separatistas apontam a drenagem de recursos que os demais estados brasileiros realizam no Rio Grande do Sul, apostando na emancipação como alternativa para que os recursos regionais permaneçam no estado, favorecendo o crescimento da República Federal do Pampa. Procuram destacar que o novo país não dependeria em nada do Brasil, uma vez que os recursos locais seriam suficientes para a implantação de uma nova máquina administrativa.

Os documentos produzidos pelo movimento esforçam-se em demonstrar o potencial agrícola regional, sua produção mineral, a pecuária, o potencial turístico e hidrelétrico e o baixo retorno da arrecadação de impostos não só no Rio Grande do Sul, mas nos demais estados da região em geral.

Outro motivo de grande descontentamento dos separatistas é em relação à representatividade no Congresso Nacional:

Ao longo de todos estes anos, o Rio Grande do Sul, outrora celeiro da produção de grãos, carnes, indústrias calçadistas, entre outras culturas, hoje perdeu poder de barganha. A proporcionalidade do voto, criminosamente desigual na representatividade do sufrágio universal, tem sido um dos álibis para desviar fortunas, de regiões extremamente produtivas, em favor de regiões servidas pelo cartelismo clientelista do Palácio do Planalto, aliciadas pela carriola de políticos investidos dos piores vícios contra seu próprio povo e sua gente. (idem)

[...] A situação não é nova, nas últimas décadas o Rio Grande do Sul teve uma evasão líquida de recursos que supera o que foi investido pelos americanos para reconstruir a Europa após a Segunda Guerra Mundial através do European Recovery Program (mais conhecido como Plano Marshall)... lá eles reconstruíram um continente, e aqui? o que os brasileiros fizeram com tanto dinheiro? (idem) 
Do total de parlamentares em Brasília (Senadores e Deputados) 70\% é composto por representantes de regiões brasileiras que produzem $30 \%$ do PIB brasileiro e 30\% dos representantes políticos em Brasília são de regiões que produzem 70\% do PIB. Cada Deputado do Sul/Sudeste representa 341.870 habitantes. No Norte, Nordeste e Centro-Oeste, cada Deputado equivale a 240.078 habitantes. NoSenado a desproporção na representatividadeé maior ainda. No Sul e Sudeste a relação é um senador para cada 4.004.762 habitantes. No Norte/Nordeste/Centro-Oesteé de um senador para cada 1.028.833 habitantes. (idem)

Os separatistas alegam que a autonomia do sul do Brasil irá beneficiar a nação brasileira (os estados que continuarem a formar o Brasil), uma vez que irão perceber o conservadorismo e a corrupção que assola o País e terão de escolher novos representantes, podendo, assim, deixar de lado o paternalismo e o coronelismo:

Logo a inconstitucionalidade é vertente no Art. 14º da Constituição Federal do Brasil. Como exemplo: um deputado do Amapá representa 14.768 votos, um deSão Paulo representa 308.350 votos e outro do RS representa 183.866 votos. Porém cada um deles tem o mesmo peso de um voto nas decisões da Câmara (Art.14 Const. Fed.). O mais impressionante é que esta situação não é nova, foi introduzida em 1934 e não foi mais substancialmente alterada. É um círculo de ferro, pois a decisão de mudar esse sistema depende dos votos da maioria que é justamente beneficiada por ele. Na distribuição de verbas o processo é mais gritante ainda. Por estas e outras tantas razões a região Sul, em especial o Rio Grande do Sul, através do processo plebiscitário buscará a sua separação ou afastamento do resto do Brasil, para o bem da Nação Brasileira. Só assim, o povo haverá de escolher os verdadeiros e dignos representantes da Nação Brasileira, escolhendo os que têm amor à Pátria e que não sejam estes apátridos que aí estão hoje emperrados no poder como ostras presas a um casco deteriorado ao fundo do mar. $\mathrm{O}$ Conservadorismo é o câncer brasileiro!! (idem) 
Além dessas diferenciações políticas, históricas e econômicas, os separatistas tentaram se apropriar do que denominam cultura gaúcha com o intuito de diferenciar ainda mais o Rio Grande do Sul dos demais estados brasileiros:

O Folclore e tradicionalismo gaúcho, sem dúvida, estão entre os mais lindos. A arte, a poesia, o churrasco, o chimarrão, a bombacha, o comportamento social, a lida campeira... personalizam seu hábito e tradição que, de geração em geração, perpetuam suas raízes. Estamos muito mais próximos da cultura platina hispânica que brasileira. Em convívio entre Portugueses, Espanhóis, Alemães, Italianos, Nipônicos e nativos-crioulos, as culturas se adaptaram cada uma com as suas características e culto. (idem)

[...] Como em muitas outras regiões do mundo, e com o Mapa geopolítico dividido de forma arbitrária, povos e culturas lutam por justiça social. Dividiu-se territórios, esquecendo-se do mais elementar: A NAÇÃO (povo). (idem)

[...] A dívida externa nos sufoca o tempo todo. Nós, gaúchos, passamos vergonha ao encararmos os estrangeiros nas nossas ruas, que nos olham com desprezo, como sendo velhacos, incompetentes e ignorantes, sem o poder de ação, quando na verdade eles não sabem que o povo gaúcho nada tem a ver com os erros técnicos e as discrepâncias do governo do Brasil. ("Manifesto do povo gaúcho" in http:// www.pampa.cjb.net)

[...] Temos a nossa própria e secular tradição, nossos próprios costumes. Pretendemos avançar no tempo, conservando nossos hábitos, mas buscando na ciência, na informática, na educação, na saúde, na habitação, nos investimentos da área agrícola, do trabalho, da tecnologia nos projetos espaciais e futurísticos, mais garantia e respeito para nossos filhos, para nossos netos e para a própria civilização gaúcha. (idem) 
Durante sua trajetória, o Movimento Separatista Sulino contemporâneo esteve associado, por diversas vezes, ao nazismo, principalmente no início da década de 1990, quando o movimento alcançou ressonância nacional. Isso ocorreu porque diversos separatistas alegaram que os gaúchos e os sulistas de modo geral são superiores aos demais habitantes do País, uma vez que os estados do sul foram colonizados em primeiro plano por alemães e italianos, e, segundo eles, a miscigenação com os negros ocorreu em grau menor do que no resto do País.

Além disso, em entrevista ao jornal Folha de S.Paulo, em 21 de fevereiro de 1993, o principal líder do movimento, Irton Marx, anunciou que a República Federal do Pampa, uma vez concretizada, fechará suas fronteiras à mão de obra não qualificada, e, em pouco tempo, o novo país se tornará o primeiro país desenvolvido da América Latina, contando com o apoio de empresários do Canadá e da África do Sul "diante da ameaça do domínio dos negros”. Segundo Irton Marx, como o Rio Grande do Sul está inserido em uma Federação, seu destino é ser comandado por "pessoas mais atrasadas", fazendo referência à representatividade no Congresso Nacional. Para ele, o ideal é o Rio Grande do Sul se unir a seus semelhantes, Paraná e Santa Catarina, e constituir uma nova pátria. Quando perguntado se sabe falar alemão, por ser um descendente, de forma descontraída Marx respondeu: "Dá para dizer heil Hitler". Irton Marx foi preso nesse mesmo ano portando material nazista e acusado de propagar a ideia nazista durante as assembleias separatistas.

No ano seguinte, Molon (1994) e Ruben George Oliven ${ }^{4}$ entrevistaram Irton Marx. Entre as perguntas, Oliven questionou sobre sua relação com o nazismo, e Irton respondeu que era uma associação muito lógica, uma vez que ele, assim

4 Ruben George Oliven é antropólogo e professor da Universidade Federal do Rio Grande doSul. Foi presidente da Associação Brasileira de Antropologia(ABA) de 2000 a 2002 eé especialista emidentidade gaúcha. 
como a maioria da população gaúcha, é descendente de alemães. $\mathrm{Na}$ verdade, acusou de existir no Brasil um racismo contra as pessoas de origem alemã e que, para desmoralizar o movimento separatista, os acusaram de racistas e, sem comentar a entrevista de 1993 para a Folha de S.Paulo, completou:

Se o Irton Marx fosse uma pessoa de origem portuguesa, espanhola, não haveria essa pressão. Agora, como eleé de origem germânica, de uma cidade germânica rica e organizada, as pessoas de imediato nos taxam como nazistas, quando, em nenhum momento, alguém do nosso movimento teceu considerações com referências étnicas, culturais ou religiosas. Agora, proibir que se fale em alemão, isso sim é que é racismo. (Molon, 1994, p.127)

Com base na leitura dos documentos do movimento separatista e dos questionários aplicados em pesquisa feita em 2003, pode-se entender que a ideia de germanismo parece apropriada a alguns discursos dos separatistas, em que a identidade étnica do gaúcho é diferenciada em relação aos demais brasileiros. A ideia de que o solo gaúcho, discriminado e explorado pelo governo brasileiro em toda sua história, só iria se libertar a partir de sua independência e autonomia nunca vem apartada do caráter étnico. Considerando que grande parte do estado do Rio Grande do Sul foi colonizada por alemães e que há notícias de que militantes do Movimento Separatista Sulino contemporâneo demonstram sua simpatia por princípios nazistas, é possível configurar a influência do nazismo-germanismo no movimento.

Em 2003, como parte da dissertação de mestrado em Ciências Sociais, realizou-se uma pesquisa de campo com o propósito de identificar qual era a repercussão do movimento separatista entre a população de algumas cidades. A pesquisa foi feita nas cidades gaúchas de Santa Rosa, Tucunduva, Ijuí, Porto Alegre e São Leopoldo. No total, escolheram-se, de forma aleatória, 850 pessoas, de várias origens, idade, classe social e de ambos os sexos. 
O resultado da pesquisa apontou o seguinte: $86 \%$ dos entrevistados conheciam o movimento separatista e 46\% se manifestaram a favor da emancipação dos estados do sul. Entre os entrevistados favoráveis à separação, 32\% acreditavam que são motivos políticos que impulsionam a vontade de separação. O segundo maior motivo para a separação é o de ordem cultural, com $29 \%$ dos votos. O terceiro motivo alegado pelos entrevistados são os fatores históricos, com $21 \%$ dos votos. Entre aqueles que não eram favoráveis à separação (54\%), o principal motivo para os estados do sul continuarem integrados ao Brasil se concentrava na afirmação de que, para haver a separação, seria necessária uma guerra armada, com $38 \%$ dos votos.

Outras pesquisas feitas para compreender a repercussão do movimento no sul do Brasil podem ser mencionadas. Segundo dados do movimento separatista, em 1985 mais de 9 milhões de habitantes do Rio Grande do Sul eram favoráveis à emancipação: ${ }^{5}$

Somos mais de 9 milhões de seres humanos nas mãos dos brasileiros, por causa da nossa anexação ao seu território. Somos mais de 9 milhões de sofredores nas mãos de politiqueiros, de interesseiros nacionais e estrangeiros. Temos um belo território com cerca de 282.184 km2, se juntado ao de Santa Catarina, chegaremos a $378.169 \mathrm{~km} 2$, com uma população estimada para o ano de 1990 em cerca de 13 milhões de pessoas habilitadas a fazer prosperar a República do PAMPA GAÚCHO. ("Manifesto do povo gaúcho" in http://www.pampa.cjb.net)

Outras pesquisas foram realizadas no decorrer dos anos. Em maio de 1993, o DataFolha organizou uma pesquisa de âmbito nacional para apurar a adesão ao movimento sepa-

5 Em 2000, os separatistas tentaram organizar um plebiscito para calcular a adesão ao movimento, mas, por motivos políticos não divulgados, o evento não aconteceu. 
ratista gaúcho. Foram ouvidas 5.078 pessoas nos estados de São Paulo, Rio de Janeiro, Minas Gerais, Rio Grande do Sul, Paraná, Bahia, Ceará, Pernambuco, Pará e Distrito Federal. De acordo com o DataFolha, 32\% da população de Porto Alegre se dizia favorável à independência dos estados do sul do Brasil. Em Curitiba, a aceitação era de 27\%. Em São Paulo, 19\% se diziam favoráveis à independência dos estados do sul e 9\% desejavam um país constituído somente por São Paulo. A pesquisa apurou que 18\% dos cearenses eram a favor de um novo país formado pelos estados do sul do Brasil e 21\% almejavam a união de Ceará e seus vizinhos para formar um novo país. O maior índice de rejeição foi encontrado em Brasília, onde 91\% eram contrários à emancipação dos estados do sul.

Em resumo, os números do DataFolha revelaram que 19\% da população brasileira se dizia favorável à criação da República Federal do Pampa. Para 32\% dos brasileiros, os estados do sul do país seriam beneficiados com a sua emancipação e 13\% acreditavam que essa emancipação seria benéfica para os demais estados que permanecessem integrados à União.

Uma outra pesquisa foi feita em 1996 pelo Instituto Bonilha de Curitiba para a revista IstoÉ, edição número 1235. Essa pesquisa revelou que $43,1 \%$ dos entrevistados dos estados do sul e de São Paulo, se votassem em um plebiscito sobre a separação de seus estados, diriam sim. De acordo com o instituto, $49 \%$ dos catarinenses e $47 \%$ dos gaúchos votariam pela emancipação.

$\mathrm{O}$ que se pode constatar com essas pesquisas é que os números apontam para uma consciência de autonomia entre os brasileiros, de modo geral, e entre os gaúchos de modo particular. No entanto, há que se ponderar que muitas das informações são transmitidas à população de forma emocional, invocando a história e os antepassados gaúchos, apresentados como heróis e proprietários legítimos daquele chão: 
Queremos respirar o nosso ar puro dos pampas e das planícies, queremos sentir as brisas que cortam por entre as coxilhas gaúchas, onde estão enterrados nossos queridos antepassados, que jazem na esperança de ver esta terra bendita livre e soberana, conduzida por homens honestos, briosos, e que amem antes de tudo sua terra e sua gente. Temos que respeitar todos aqueles que tombaram com este sonho separatista, pois esta é a chama que mantém viva a data de 20 de setembro, como marco de orgulho da nação gaúcha. Eestamos dispostos a também morrer por esta causa nobre e tão sonhada por cada um de nós. (idem)

Não se devem ignorar, entretanto, alguns números expressivos que apontam para uma insatisfação dos gaúchos em relação às condições do País, pois é notório que o Brasil vem passando, nos últimos anos, por crises econômicas e sociais, principalmente nos grandes centros. Os separatistas apropriam-se do sentimento de descontentamento da população em geral e o utilizam em seus discursos:

O Brasilé um país desequilibrado social eeconomicamente, com acentuadas agravantes que ocorrem no dia a dia. Certamente todos aqueles que divergirem dos interesses políticos, visando buscar o bem social, estão prestes a serem eliminados, a exemplo dos separatistas que nada mais buscam senão o bem social, econômico, educacional para a população oprimida, massacrada e explorada do Rio Grande do Sul. Estamos denunciando aos quatro cantos do mundo, inclusive a este órgão defensor dos elementares direitos de autodeterminação dos povos, que amanhã nosso direito de autodeterminação e a nossa liberdade de expressão estarão eliminados do caminho da máfia do poder constituído pelas oligarquias políticas do Brasil. Os dirigentes que militam e dirigem o Movimento Nacionalista Pampa, visando buscar sua Independência, jamais incitaram um processo violento ou bélico, mas de forma alguma deixaremos nos agredir. Estaremos sempre alertas contra todo e qualquer ataque do Brasil contra os dirigentes do Movimento Pampa. (carta enviada à Organização das Nações Unidas (ONU) in http://www.pampa.cjb.net) 
Os 160 milhões de habitantes do Brasil vivem realidades extremamente distintas de Norte a Sul do País. O desemprego galopante e assustador; a falta de investimento na área social, a falta de uma política séria voltada à manutenção social; a forma selvagem como vem se destruindo a agricultura brasileira, reprimindo e prendendo pessoas que buscam uma forma de contribuir ao crescimento na produção de grãos; a invasão do Brasil em outros territórios, impondo regras perversas a Estados e até mesmo a Países pequenos, é uma demonstração clara de desrespeito, prepotência e de inviabilidade de qualquer projeto político, social e econômico. Esta vertente de despotismo e de agressão vem se acentuado e agravando desde o tempo do Império. Basta a tudo isto!!! (idem)

Os separatistas fazem uso da simbologia com o propósito de fortalecer seus ideais, remetendo sempre a grandes personagens da história gaúcha. Divulgaram em sua página na internet o desenho do mapa geopolítico estabelecido a partir da emancipação dos estados do sul do Brasil. Também criaram uma bandeira para o novo país, descrita na carta que os separatistas enviaram à ONU:

O nome "PAMPA" vem ao encontro da característica geográfica na proposição geo-política do novo País. O globo da Bandeira do Movimento pela Independência homenageia um círculo perfeito da humanidade no período de vida de todos os seres que ocupam lugar em algum espaço. A referência das vias cruzadas tem como fato acolhedor a todos os caminhos convergentes e divergentes ao centro do novo País que inicia sempre um renovador ciclo de vida. A cor azul representa o novo início. Como um corpo celestial novo, cheio de vida nova. A cor vermelha vem enaltecer e contemplar a bravura e determinação de seus idealizadores e um grande número de simpatizantes, de um povo que luta pela conquista de seus ideais. Ideais balizados ao da Independência do novo País. O próprio Brasil, por questões econômicas, e em defesa de sua célula máter, se desmembrou de Portugal. Os mesmos direitos cabem hoje aos 
filhos da outra parte da extinta província Cisplatina. Aliás, que nunca pertenceu ao Brasil por direito internacional avalizado pelo processo do "Utis Posseidetis". (idem)

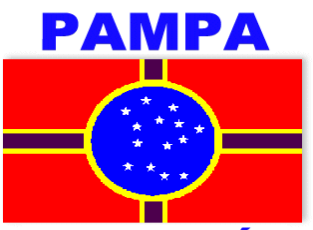

MEU PAÍs

A criação de uma bandeira para representar a República Federal do Pampa, segundo seus idealizadores, está ligada à necessidade de amparo dessa nova nação. Os filhos dessa nova pátria precisariam se sentir acolhidos e representados, e a bandeira é o recurso visual mais eficiente na situação.

A seguir, apresentam-se os mapas geopolíticos da América doSul e da República Federal do Pampa, segundo os separatistas, propostos a partir da emancipação do sul do Brasil.

AMÉRICA DO SUL (SOUTH AMERICA)

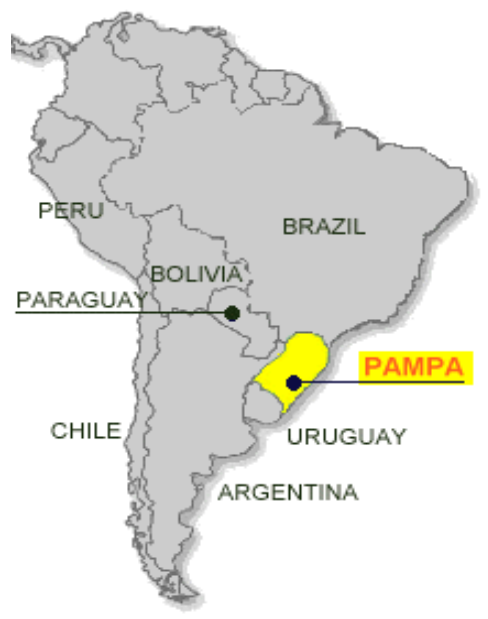




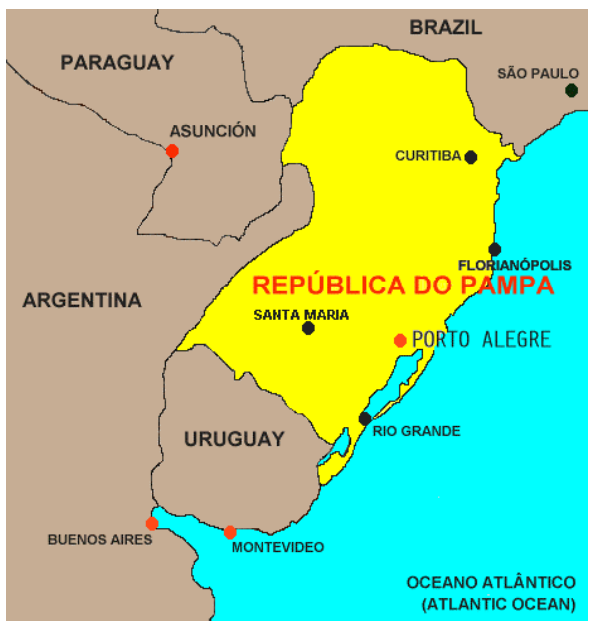

Em entrevista reproduzida pela Folha de S.Paulo, em 12 de julho de 1993, o sociólogo Edgar Morin, estudioso do tema nacionalismo, fez algumas considerações sobre a questão separatista que podem auxiliar na compreensão desse fenômeno no sul do Brasil e, em especial, no Rio Grande do Sul.

Para Morin, o processo de revitalização pelo qual passa atualmente a dimensão da nacionalidade faz parte de um retorno às origens que abrange o mundo todo: "[...] quando o futuro está perdido, podemos nos concentrar no presente. Quando o presente está enfermo, refugiamo-nos no passado e revalorizamos as raízes étnicas, nacionais, religiosas". $\mathrm{O}$ retorno às origens parece ser inevitável para Morin, e o nacionalismo é uma expressão desse retorno. A solução proposta pelo sociólogo, para que a busca pela emancipação não tenha um resultado catastrófico - como se pode observar em outros movimentos separatistas espalhados pelo mundo, a exemplo da Iugoslávia, onde a situação retrata uma guerra -, é operar um retorno para a origem, de modo mais amplo, mais profundo. Além do sentimento de nacionalidade ou territoriedade observado entre os separatistas, deve-se buscar atingir a ideia de "Terra-Pátria": 
Aquém dos nossos ancestrais culturais, temos ancestrais primordiais nas próprias origens da humanidade [...]. Participamos da mesma identidade terrena, da mesma identidade humana. Assim o retorno às origens em profundidade faz de nós irmãos em humanidade. Ao mesmo tempo a consciência da nossa era planetária nos torna cidadãos do mundo, que poderíamos e deveríamos estar conscientes do nosso destino comum. Minha idéia, em suma, é não opor o desenraizamento ao enraizamento. É promover o grande reenraizamento na Terra-Pátria. (Edgar Morin. Folha de S.Paulo, 12.7.1993)

Nesse sentido, há que se recorrer às afirmações de Lévi-Strauss, já de muito conhecidas: "a humanidade está constantemente às voltas com dois processos contraditórios, um dos quais tende a instaurar a unificação, enquanto o outro visa a manter ou restabelecer a diversificação" (cf. Lévi-Strauss et al., 1970, p.268). O autor esclarece que as diferenças não deveriam ser entendidas como algo excludente e exclusivo, mas como experiências sociológicas diversas da nossa, mesmo que o devir histórico tenha se incumbido de realizar a osmose cultural, e isso porque nós e eles pertencemos agora a uma mesma história, regida pelo caráter unidimensional da técnica e do progresso.

Para Lévi-Strauss (1980, p.97):

A necessidade de preservar a diversidade das culturas num mundo ameaçado pela monotonia não escapou certamente às instituições internacionais. Elas compreendem também que não será suficiente, para atingir esse fim, animar as tradições locais e conceder uma trégua aos tempos passados. É a diversidade que deve ser salva, não o conteúdo histórico que cada época lhe deu e que nenhuma poderia perpetuar para além de si mesma. É necessário, pois, encorajar as potencialidades secretas, despertar todas as vocações para a vida em comum que a história tem de reserva; é necessário também estar pronto para encarar sem surpresa, sem repugnância e sem revolta o que estas novas formas sociais de expressão poderão oferecer 
de desusado. A tolerância não é uma posição contemplativa dispensando indulgências ao que foi e ao que é. É uma atitude dinâmica, que consiste em prever, em compreender e em promover o que quer ser. A diversidade das culturas humanas está atrás de nós, à nossa volta e à nossa frente.

As culturas não diferem entre si do mesmo modo, nem no mesmo plano. A diversidade, portanto, é fundamental. 



\section{4 \\ TRADIÇÃO SEPARATISTA}

\section{A Revolução Farroupilha (1835-1845)}

Foi preciso que os farroupilhas, numa peleja titânica, dequase dez anos propagassem aos quatro ventos seus anseios de liberdade e dissessem ao Brasil que dele se separavam, como se separaram, enquanto não lhes fosse concedido quanto desejavam e que era, simplesmente, Igualdade e Justiça. (Spalding, 1963, p.166)

Após a deposição de D. Pedro I em 7 de abril de 1831, por causa de sua impopularidade, foram promovidas reformas institucionais que ampliaram a base de apoio do regime regencial, mas sem satisfazer as reivindicações provinciais que tinham como maior exigência a eleição direta dos presidentes das províncias. A partir daí, surgiram no Brasil vários movimentos políticos e armados: em Pernambuco (1831-1835), no Ceará (1831-1832), em Minas Gerais (1833-1835), no Grão-Pará(1835-1840), no Rio Grande do Sul (1835-1845), na Bahia (1837-1838), no Maranhão (1838-1841). Alguns desses movimentos ganharam forte conteúdo social, como é o caso da Balaiada, no Maranhão, e da Cabanagem, no Grão-Pará. Mas éa Revolução Farroupilha ocorrida no Rio Grande do Sul que interessa tratar aqui. 
A Revolução Farroupilha tinha a intenção de proclamar uma república independente nos moldes do liberalismo em voga na Europa. Nasceu em razão do descontentamento dos estancieiros gaúchos em relaçãoà política exercida pelo governo central, que submetia as províncias a uma situação de subordinação, um centralismo político que abocanhava grande parte das rendas produzidas no sul, sem investi-las na região. Os estancieiros buscavam o fim da dependência econômica com o centro do País, com o propósito de vender seu gado para as charqueadas gaúchas ou uruguaias com impostos reduzidos. Segundo Maestri (2001a), o movimento assumiu caráter separatista e republicano, apesar de essas orientações serem possivelmente minoritárias quando da eclosão da revolta.

A historiadora Sandra Jatahy Pesavento (1986), em A Revolução Farroupilha, concede especial atenção ao processo de formação da revolução. Segundo ela, quando começou a chamada Revolução Farroupilha, no ano de 1835, a província do Rio Grande doSulera ainda pouco povoada, com pouco mais de 400 mil habitantes. Existiam apenas 14 municípios, sendo Porto Alegre, Rio Grande e Pelotas os mais importantes.

Tratava-se de uma província isolada, onde as comunicações eram bastante precárias, não havia uma só ponte, e a principal forma de transporte restringia-se ao cavalo ou às carroças. Também se utilizavam os rios Taquari, Jacuí e Caí, que distribuíam os produtos chegados ao local trazidos por embarcações ou tropas de outras províncias. Muitos dos produtos tinham origem na Europa: eram vassouras, fósforos, tecidos, acessórios, sapatos etc. Nesse período, o Rio Grande do Sul exportava o charque para as demais regiões do País e o couro para o exterior.

$\mathrm{O}$ isolamento da província não garantia uma vida pacata e parada. O povo gaúcho teve de lutar contra os espanhóis para garantir suas terras e, no período entre 1817 e 1825, enfrentou problemas de fronteira com o Uruguai, quando este foi incorporado ao Brasil (1821-1828). 
Foi em 20 de abril de 1835 que a história farroupilha começou a ser escrita. Logo que se iniciou a primeira sessão da Assembleia Provincial, o presidente da província, Antônio Rodrigues Fernandes Braga, ${ }^{1}$ denunciou a existência de um plano para separar o Rio Grande do Sul do Império e uni-lo ao Uruguai, com o apoio do uruguaio Juan Lavalleja, que lutava para unificar o Uruguai, o Rio Grande do Sul, Entre Rios e Corrientes em um só grande Estado. A acusação também se dirigia a Bento Gonçalves da Silva, liberal extremado, que, além de ser um importante chefe militar, era de uma rica e poderosa família de estancieiros gaúchos. Segundo Maestri (2001a), essa intenção era unânime entre o Partido Liberal sul-rio-grandense e não conseguiu ser comprovada na ocasião.

Segundo a Constituição vigente, a de 1824, cada província recebia do governo central uma quantia em dinheiro para custear suas despesas. Quando havia déficit, o governo enviava mais dinheiro, mas, no caso de superávit, apropriava-se do dinheiro e o utilizava como desejasse. Para o Rio Grande do Sul que quase sempre tinha um superávit, essa situação era de grande insatisfação, principalmente porque a província carecia de alguns benefícios, e esse dinheiro se fazia necessário. ${ }^{2}$

Outro grande descontentamento dos farroupilhas era em relação ao controle alfandegário - descontentamento, aliás, que ainda existe nos dias de hoje. ${ }^{3}$ As taxas de exportação e

1 Fernandes Braga era um republicano moderado e assumiu a presidência da província sob indicação de Bento Gonçalves, na ocasião um dos líderes do Partido Liberal.

2 O caso que mais chamou atenção ocorreu em 1832, quando 24 contos de réis do superávit gaúcho foram utilizados para cobrir o déficit de Santa Catarina. O governo central também utilizou o dinheiro do superávit gaúcho para pagar empréstimos que havia feito com a Inglaterra (Pesavento, 1986).

3 Um dos argumentos separatistas para reivindicar a autonomia da Região Sul está baseado na questão das disparidades no setor fiscal entre os estados brasileiros, ainda hoje central nas discussões no Congresso e Senado Federal. 
importação de produtos eram muito altas, o que prejudicava o comércio gaúcho. Além das taxas alfandegárias cobradas por cada produto que entrava no Império, cobrava-se uma taxa também quando este vinha para a província. Além de encarecer os produtos, muitos não chegavam ao Rio Grande do Sul. Para as exportações, taxas menores cobradas em outras províncias desestimulavam o comércio com os produtos gaúchos, que acabavam ficando encalhados.

Ressentimentos levaram à explosão de hostilidades, centradas em torno de taxas de "exportação" um tanto elevadas que impossibilitavam ao charque Sul-rio-grandense competir com os preços oferecidos no Rio pelos produtores da região platina, economicamente em expansão. (Love, 1975, p.14)

À medida que a crise na sociedade sul-rio-grandense ia se agravando, o sentimento de revolta crescia entre a população gaúcha: “'Abandonando a esperança de retribuição satisfatória dentro do Império, os gaúchos começaram a lutar pela independência em 20 de setembro de 1835" (idem).

A partir daí, as forças liberais chefiadas por Bento Gonçalves reuniram praticamente toda a oposição da província, liberais moderados monarquistas, liberais moderados republicanos e separatistas. Após a tomada de Porto Alegreem 21 de setembro, os revoltosos receberam a alcunha de farroupilhas, um termo pejorativo, mas que foi aceito com orgulho. Conseguiram afastar o presidente da província, Fernandes Braga, justificando seu ato como simples deposição de um presidente incapaz, faccioso e antiliberal (Maestri, 2001a).

4 Segundo Pesavento (1986), os descontentamentos se acumulavam não só no Rio Grande do Sul, mas também em outras partes do País, onde a economia ainda era subsidiária. Isso propiciou a eclosão de uma série de rebeliões provinciais, citadas anteriormente, marcadas por ideias federativas e republicanas, denotando a presença das oligarquias locais insatisfeitas contra a política imperial. 
Em pouco tempo, Porto Alegre, Rio Pardo, Rio Grande, Pelotas e Piratini encontravam-se nas mãos dos rebeldes, que seapressaram em tranquilizar os ricos comerciantes portugueses. Uma série de pequenos confrontos passou a suceder. Um dos primeiros ocorreu em 17 de março de 1836 quando Bento Manuel ${ }^{5}$ derrotou os farroupilhas, matando mais de 200 soldados rebeldes. Em seguida, em junho de 1836, os farroupilhas perderam a posse de Porto Alegre em um combate quando a cidade foi atacada por mar e por terra, em que os farroupilhas perderam praticamente toda a sua frota. A perda de Porto Alegre foi muito sentida, pois assinalava a clara anexação ao império do comércio, artesanato e dos grandes escravistas.

Após a derrota em Porto Alegre, o exército farroupilha teve de recrutar muitos homens para combaterem nos inúmeros confrontos subsequentes. Finalmente, em 11 de setembro de 1836, o coronel farroupilha Antônio de Souza Neto proclamou em Piratini, próximo à fronteira com o Uruguai, a separação da província e a República Sul-rio-grandense:

Camaradas! Nós que compomos a $1^{\text {a }}$ Brigada do exército liberal, devemos ser os primeiros a proclamar, como proclamamos, a independência desta província, a qual fica desligada das demais do Império e forma um Estado livre e independente, com o título de República Sul-rio-grandense [...].

A República que ficou conhecida por seus inimigos como a República de Piratini adotou a forma republicana de governo.

Duas semanas após a proclamação da República Sulrio-grandense, Bento Manuel organizou uma emboscada em que foram presos Bento Gonçalves e seus principais

5 Bento Manuel Ribeiro, de Alegrete, era comandante das Armas da província, mas não se decidia se queria lutar ao lado dos farroupilhas ou se iria permanecer ao lado do Império. Por diversas vezes, mudou sua estratégia de combate, ora defendendo os ideais farroupilhas ora sua boa posição no Império. 
comandantes, Onofre Pires e Corte Real, com mais de mil soldados farroupilhas. Após o julgamento, os líderes rebeldes foram enviados presos para o norte do Brasil. Os farroupilhas organizaram o primeiro governo da República, elegendo Bento Gonçalves como seu presidente e o coronel José Gomes de Vasconcelos Jardim para substituí-lo enquanto estivesse preso. Bento Gonçalves permaneceu preso na Bahia de novembro de 1836 até 10 de setembro de 1837. Em 16 de dezembro de 1937, assumiu a presidência da República Sul-rio-grandense.

Conforme descrevem Pesavento(1986)e Maestri(2001a), o governo republicano instituiu ministérios, repartições públicas, pensão para os dependentes de militares mortos em combate e determinou que se abrissem escolas em todos os municípios. Um serviço de correio também foi organizado ea melhoria dos meios de comunicação criou uma tipografia e um jornal oficiais: O Povo. Utilizando mão de obra escrava, foram organizadas manufaturas de carretas, curtume, erva-mate, ferraria, fumo, selaria, mas a economia da República continuou baseada na produção e exportação de charque, couro e sebo.

Nessa ocasião, os imperiais já haviam tomado Porto Alegre e também a região dos portos. Procurando uma saída para o mar para poder sustentar a República, os republicanos invadiram Santa Catarina sob o comando do comandante farroupilha David Canabarro, que organizou o ataque a Laguna, apoiado por Garibaldi. ${ }^{6}$ Após a conquista de Laguna, foi proclamada a República Juliana, em 13 de setembro de 1839, república que durou menos de dois meses, por causa da reação das tropas imperiais e da ineficiência de seu presidente, Canabarro (Andrade, 1997).

6 Garibaldi, corsário italiano jurado de morte em seu país, havia assinado carta de corso com a República, segundo a qual ela aparelhava os navios e os comandantes obrigavam-se a entregar a metade das presas ao governo e a indenizar os tripulantes e os armadores dos navios. A iniciativa não trouxe frutos reais para a República. 
A primeira tentativa de paz se deu em 1840, após ter sido declarada a maioridade de D. Pedro, estabelecida por um golpe dos liberais em 27 de julho do mesmo ano. O tratado de paz concedia anistia aos republicanos em troca da adesão ao Império. Esse tratado foi renegado porque não propunha a federação do Rio Grande do Sul com o Império e não reconhecia a liberdade dos soldados negros, como defendiam alguns dos generais farroupilhas.

Já em 1842, a atividade bélica farroupilha passou por uma grande crise, assinalando o início da decadência da República Sul-rio-grandense. Essa crise agravou-se quando o barão de Caxias ${ }^{7}$ assumiu a chefia da província e das tropas imperiais, contando com todo o apoio necessário por parte do Império para derrotar os farroupilhas.

Foi Bento Gonçalves quem iniciou as discussões de paz com Caxias no ano de 1844. Após muita discordância e desconfiança entre os farrapos, Bento Gonçalves abandonou a luta e retirou-se para sua estância. As negociações de paz ficaram nas mãos dos chefes farroupilhas que estavam muito mais preocupados em sair da conjuntura nas melhores condições possíveis do que em oferecer para os gaúchos uma esperança de reconstruir a província.

A paz foi assinada em $1^{\circ}$ de março de 1845 com a rendição farroupilha. Era o tratado de Poncho Verde que reconhecia Caxias como presidente da província, deixando todas as dívidas republicanas para o Império. Os oficiais foram transferidos para as tropas imperiais, e libertaram-se os soldados negros. Estavam decretadas a vitória do Império e a nova relação de forças entre as elites sulinas e o centro. Ao

7 Caxias assumiu a liderança da província do Rio Grande do Sul graças a seu prestígio pela derrota da Balaiada no Maranhão, onde massacrou os membros das classes subalternas que participaram do movimento. No Rio Grande do Sul, as tropas da Guarda Nacional, sob as ordens de Caxias, alcançavam 22 mil homens, enquanto os farroupilhas possuíam pouco mais de mil soldados, mal-armados e mal-abastecidos. 
mesmo tempo que o Rio Grande do Sul permanecia como parte integrante da nação, a hegemonia política regional da aristocracia agrária gaúcha passou a ser reconhecida. Os escravos e os gaúchos que lutaram nas tropas farroupilhas e imperiais ajudaram a consolidar a nova relação de forças e o domínio da aristocracia agrária.

Algumas facções farroupilhas tiveram um caráter libertário por causa de algumas medidas dos chefes farroupilhas em relação ao negro escravizado. Para Clóvis Moura (1981, p.87), "[...] afora a insurreição dos alfaiates, na Bahia, nenhum outro movimento foi tão enfática e ostensivamente anti-escravista como o chefiado por Bento Gonçalves". Boa parte dos trabalhos rurais e urbanos sulinos apoiava-se nas costas dos negros escravizados. Eram eles que consolidavam a unidade das elites sul-rio-grandenses. Discordando dessa opinião, Leitman (1979, p.46) afirma que os farroupilhas não pretenderam a abolição ou a reforma da escravatura:

Os chefes farrapos não eram revolucionários sociais empenhados em reestruturar as relações de classes. Na melhor das hipóteses, eram o produto do tempo, incapazes de ultrapassar as atitudes sociais tradicionais. Qualquer colapso nas relações tradicionais entre senhor e escravo, estancieiro e gaúcho, poderia desorganizar o sistema político e social vigente.

Apesar de fazendeiros, charqueadores, homens livres e escravos lutarem lado a lado na Revolução Farroupilha, a extensa maioria dos trabalhadores pastoris e dos escravos jamais possuiu algum ideário político ou social em comunhão com seus patrões. Os fazendeiros e charqueadores lutaram para ampliar suas riquezas e poder, mas os peões, os pobres e os escravos jamais defenderam seus próprios interesses. Na maioria das vezes, apenas cumpriam as ordens de seus senhores. Mas isso não quer dizer que a revolução, com duração de uma década, não lhes dissesse respeito. 
Portanto, na Revolução Farroupilha, não estavam em jogo a organização social, o destino dos trabalhadores escravizados, muito menos o acesso à terra dos gaúchos.

Existiam algumas contradições nas reivindicações dos fazendeiros e charqueadores, principalmente no que dizia respeito aos impostos, cindindo os farroupilhas em seus objetivos. Ainda, boa parte do grande comércio continuou em mãos de lusitanos. Isso explica por que apenas um setor das elites sulinas aderiu à revolta. As elites dividiram-se em várias posições que iam do republicanismo extremado até o legalismo fervoroso. A grande base social farroupilha foi quase sempre os estancieiros do sudeste gaúcho. Porém, havia uma fundamental convergência de opiniões unindo todos os senhores sul-rio-grandenses: tratava-se de uma disputa política entre as elites e era necessário manter as classes subalternas na dominação. Apenas a incapacidade de os republicanos conquistarem a adesão da burguesia comercial, das frágeis classes médias urbanas, dos estancieiros serranos e dos pequenos proprietários coloniais explica por que os farroupilhas foram incapazes de controlar os principais centros urbanos, ficando centralizados na Campanha (Maestri, 2001a).

Quase duzentos anos se passaram após o início da Revolução Farroupilha, mas esse tempo não foi suficiente para apagar esse momento histórico e seus principais personagens. Para muitos gaúchos, hoje, o significado da Revolução está pautado na luta para manter aceso o tradicionalismo gaúcho e a autonomia do estado. No Rio Grande do Sul, dia 20 de setembro é feriado estadual, é o Dia do Gaúcho, dia em que os tradicionalistas desfilam o orgulho gaúcho.

Reintegrado ao Brasil, o Rio Grande doSul teve deenfrentar um outro conflito, mais curto, porém não menos importante, no qual as ideias de autonomia foram novamente levantadas. Foi a Revolução Federalista de Silveira Martins contra o presidente Floriano Peixoto, na década de 1890 (Love, 1975). 


\section{A Revolução Federalista (1893-1895)}

Entre 1872 e 1890, a sociedade gaúcha sofreu mudanças em sua economia e, consequentemente, na forma de pensar a vida gaúcha. Essas mudanças foram acompanhadas por um aumento na população da província, de 447 mil habitantes para 897 mil. Esse aumento provinha principalmente da imigração: entre 1874 e 1889, 60 mil imigrantes, a maioria vinda da Alemanha e Itália, estabeleceram-se na província. Somente em 1891, ano máximo da imigração no Rio Grande do Sul, 20.739 imigrantes chegaram à província.

Durante o Segundo Reinado (1840-1889), o desenvolvimento da cafeicultura no centro-sul relançou a criação de mulas para o transporte e a produção de charque. Segundo Love (1975), com todas essas mudanças, era natural que a política local sofresse transformações. A boa conjuntura permitiu que as elites pastoris retornassem ao poder político regional, por intermédio do Partido Liberal, hegemônico no Rio Grande do Sul de 1866 a 1889. O Partido Liberal expressava os criadores da região que haviam dirigido a revolta de 1835. Pela importância dos cativos nas fazendas e charqueadas, os liberais defendiam a escravidão.

Ainda, os liberais reivindicaram facilmente a memória farroupilha, que permanecia propriedade das classes pastoris, como no passado. Porém, monarquistas, defendendo apenas a descentralização do poder imperial, abandonavam duas grandes bandeiras farroupilhas - a separação e a república.

Em fevereiro de 1882, os republicanos gaúchos organizaram o Partido Republicano Sul-rio-grandense(PRR). Em seu Manifesto Republicano, que se baseava no Manifesto Republicano de 1870, escrito no Rio de Janeiro, os gaúchos adotaram as palavras de ordem "Centralização-Desmembramento. Descentralização - Unidade”. Logo, o PRR foi controlado por jovens filhos de ricas famílias de criadores, 
em boa parte do centro-norte do Rio Grande do Sul, chegados, sobretudo, da escola de Direito de São Paulo. Eles defendiam a modernização conservadora da província.

O PRR divulgava de forma intensa as ideias republicana e federalista. Os jovens jacobinos defendiam a autonomia regional e a diversificação produtiva, por causa da estagnação da economia pastoril-charqueadora. A República Farrapa tornava-se referência da propaganda dos positivistas radicais. Assim, a memória farroupilha era apropriada por grupos sociais, política e geograficamente estranhos ao movimento. O progresso do partido deu-se, principalmente, por causa dos esforços de quatro advogados que se destacaram no cenário gaúcho: Assis Brasil, Júlio de Castilhos, José Gomes Pinheiro Machado e Antônio Augusto Borges de Medeiros.

O PRR, apesar de muito popular, sempre perdia as eleições para o Partido Liberal, e foi assim durante toda a década de 1880. Em 1887, Júlio de Castilhos foi efetivado como chefe do PRR, e os republicanos sul-rio-grandenses comprometeram-se em uma ação revolucionária para derrubar a monarquia. Momentos antes da República, Júlio de Castilhos propôs a celebração do 20 de Setembro. Com o golpe antimonárquico de 15 de novembro de 1889, os republicanos sulinos dominaram o poder regional, institucionalizando a leitura positivista do passado farroupilha. Em 14 de julho de 1891, promulgava-se a Constituição republicana sulina, com anteprojeto de Júlio de Castilhos.

Para que pudessem manter-se no poder e programar o novo projeto, os republicanos ameaçaram as forças pastoris sulistas. Durante o confronto, os fazendeiros, herdeiros sociais, políticos e territoriais dos liberais e dos farroupilhas, reunidos sob a nova bandeira federalista, foram acusados de monarquistas e de separatistas pelos castilhistas, a memória farroupilha escorregava manipulada para as mãos dos republicanos do PRR. 
Para Maestri (2001a), na nova versão, a memória farroupilha passava a ser herança de todo sulino, não importando sua origem étnica, sua origem social, sua região de nascimento etc. Manipulava-se a história, apresentando o movimento como de toda a população do Rio Grande, contra o estado central. O mito da unidade da população na luta por um único ideal fortalecia a proposta de comunhão de interesses dos gaúchos, estabelecendo a pilastra da ordem republicana autoritária que regeu o Rio Grande do Sul até a Revolução de 1930.

Trava-se então uma disputa por poder pelos dois principais partidos gaúchos: de um lado, o Partido Federalista que passa a reunir a elite do Partido Liberal do Império, sob a liderança de Gaspar da Silveira Martins; de outro, o Partido Republicano Sul-rio-grandense que agrupava os republicanos liderados pelo governador Júlio de Castilhos. Ancorados em bases eleitorais nas cidades do litoral e da serra, os republicanos queriam, a todo custo, manter-se no poder. Já os federalistas, que representavam os interesses dos grandes estancieiros da campanha, lutavam contra aquilo que chamavam de "tirania castilhista" e exigiam a reforma da Constituição do estado com vistas a impedir a perpetuação dos rivais no poder.

Em 1892, segundo Love (1975), emergiu uma crise no PRR e Castilhos foi obrigado a renunciar, percebendo, então, a necessidade de receber o apoio de Floriano Peixoto para tomar o poder do Estado com um golpe militar. Assim, em 17 de junho de 1892, Castilhos com sua tropa rumou para o Palácio do Governo e assumiu o poder, tornando sua autoridade completa: controlava o Executivo, o Legislativo, a polícia do Estado e os governos municipais.

Pensando em manter-se definitivamente no governo do Rio Grande do Sul, Castilhos elaborou um plano com o apoio de Floriano Peixoto: renunciou em favor de seu companheiro de partido Vitorino Monteiro, para que este 
organizasse as eleições populares e Castilhos pudesse voltar ao poder de forma legítima. O plano de Castilhos e Floriano Peixoto deu certo. Em 25 de janeiro de 1893, Júlio de Castilhos foi empossado governador do Rio Grande do Sul, o primeiro por eleições populares e o décimo oitavo governador estadual desde a Proclamação da República em 1889.

Quanto mais aumentava o prestígio de Castilhos, mais os ideais federalistas viam-se ameaçados, fracos e desmobilizados. Um dos principais objetivos dos federalistas era substituir o regime presidencialista por um regime parlamentar. Cresceu o apoio a Silveira Martins que passou a liderar não só os federalistas, mas também todos aqueles que eram contrários ao governo de Castilhos. Os federalistas perceberam que, para atingir seus objetivos, não bastava apenas derrubar Castilhos, era necessário depor também seu protetor, Floriano Peixoto.

Villalba (1897) aponta que a guerra começou em 2 de fevereiro de 1893, quando um grupo de federalistas comandados por Silveira Martins rumou para Bagé com o propósito de efetuar a primeira batalha. Esse grupo contava com o apoio de uruguaios que provinham de uma região colonizada por espanhóis vindos da Maragataria. Assim, os castilhistas e republicanos aplicaram o termo "maragatos" a todos os federalistas que, assim como os farrapos, aceitaram o termo pejorativo como um distintivo de honra. Aplicando esse termo, os republicanos pretendiam dar aos federalistas o estigma de estrangeiros, separatistas e monarquistas. Segundo o governo federal da época, contando com o apoio de alemães rebeldes, estava fortemente demonstrado o caráter antipatriota dos federalistas.

Seguiram-se muitas batalhas em solo gaúcho. Muitas delas na fronteira com o Uruguai, onde os federalistas eram mais fortes. Finalmente, em 7 de novembro de 1893, as tropas federalistas invadiram Santa Catarina e rumaram para o litoral, destinados a se juntar com as unidades navais rebeldes da Marinha. 
Gumercindo Saraiva ${ }^{8}$ não estava satisfeito com as investidas contra Castilhos e resolveu organizar uma tropa com destino ao norte, com a intenção de depor Floriano Peixoto. No dia 20 de janeiro de 1894, essa tropa toma a cidade de Curitiba, e Gumercindo dá ordens para que Floriano Peixoto renuncie, do contrário, seguiria rumando pelo norte até chegar a São Paulo.

Florianoignorou as ordens de Gumercindoe, acada batalha, morriam mais e mais homens, sem que os líderes da revolução, Silveira Martins e Júlio de Castilhos, tomassem conhecimento de toda destruição e sangue derramado. Gumercindo foi obrigado a regressar ao Rio Grande do Sul e deparou com o grosso da tropa castilhista: era final de junho de 1894. Numa batalha que durou mais de 6 horas, os federalistas sofreram mais de 400 baixas, e os republicanos, 240. Os maragatos se retiraram e a tropa de Gumercindo foi pega em uma emboscada. Gumercindo morreu com um ferimento no peito.

Tendo conhecimento de que o mais corajoso comandante federalista havia falecido, Silveira Martins reconheceu que era inútil continuar com aluta. Na capital federal, as coisas também mudaram: Prudente de Moraes substituiu Floriano Peixoto e assumiu a chefia do Executivo em novembro de 1894.

Para Prudente de Moraes, era essencial a paz no Rio Grande do Sul para que fosse afirmado o controle civil da República. Em junho de 1895, o general Inocêncio Galvão de Queiroz, comandante militar da região do Rio Grande do Sul, iniciou as conversações de paz. Em 23 de agosto de 1895, o Rio Grande do Sul estava oficialmente pacificado.

Segue a mensagem que Prudente de Moraes enviou ao Congresso, participando a pacificação:

8 O comandante das invasões federalistas era Gumercindo Saraiva, que sempre contou com muitos homens, mas nem sempre com muitas armas. As tropas castilhistas, entretanto, sempre eram numerosas e bem-armadas. 
Srs. Membros do Congresso Nacional - Cumpro o grato dever de vos communicar a terminação da lucta civil que tem perturbado a vida da República ha mais de dous annos.

Submettendo-se ao regimen legal e ás autoridades constituídas da União e do estado do Rio Grande do Sul, depuzeram as armas em 23 do corrente.

O congraçamento dos brasileiros, sob o regimen republicano, é um facto auspicioso para a nossa pátria.

Trazendo ao vosso conhecimento os documentos officiaes a elle referentes tenho a mais viva satisfação em assegurar-vos que as autoridades federaes e as do estado do Rio Grande do Sul firme e sinceramente tudo farão para que seja eficaz e fecunda á pacificação.

Capital Federal, em 26 de agosto, de 1895. - Prudente J. de Moraes Barros, Presidente da República. (Villalba, 1897, p.115)

A Revolução Federalista foi a guerra civil mais sangrenta da história do Brasil. Foram 31 meses de batalhas que produziram de 10 mil a 12 mil mortes (Pesavento, 1983).

Os principais resultados da guerra estão relacionados com a política do estado do Rio Grande do Sul. A guerra constituiu um equilibrado sistema político em torno de duas ideologias bem diferentes, presidencialismo ditatorial contra parlamentarismo, o que não acontecia em outros estados do Brasil. As mudanças sociais e econômicas, porém, somente aos poucos se tornaram aparentes. 



\section{5 \\ O NAZISMO NO Rio Grande do Sul}

O objetivo de abordar o tema nazismo não é relacioná-lo com o conceito de etnicidade ou identidade étnica, pelo menos no que se refere ao Rio Grande do Sul. O que se pretende é reconstruir um episódio da história gaúcha e, assim, apontar uma possível explicação para a origem de alguns elementos presentes nos discursos dos separatistas. Para compreender aquilo que René Gertz (1987) considera germanismo, conceito adotado nesta análise sobre o separatismo gaúcho, é necessário entenderoprocesso decriaçãodoEstadoalemãonoséculoXIX.

Como descreve Bandeira (1995), o interesse alemão pelo sul do Brasil só emergiu após sua unificação em 1871, quando o estado precisava consolidar sua economia e principalmente a união dos povos germânicos.

No auge da Revolução Francesa, os estados alemães passaram a compor a Confederação do Reno, que, com a Áustria e Prússia, permaneceu sob influência francesa imposta pelo exército napoleônico e revolucionário de 1792 a 1814. Ao fim das guerras napoleônicas, os 400 estados alemães do Sacro Império Romano (962-1806) foram limitados a 35 estados e 4 cidades livres que passaram a compor a Confederação Germânica, estabelecida no Congresso de Viena de 1815. 
Durante a primeira metade do séculoXIX, cristalizaramse na Alemanha ideais românticos que buscavam reforçar o nacionalismo, descobrindo a "verdadeira essência da nação germânica”. Contudo, esses ideais não eram suficientes para estabelecer a unificação, e o que, realmente, acelerou esse processo foi a necessidade de desenvolvimento econômico. Dessa forma, em 1834 foi criado o Zollverein, União Federal de Direitos Aduaneiros, que provocou o aceleramento do progresso econômico.

No período de 1830 a 1848 , houve na Alemanha uma expansão industrial acentuada, mas a agricultura continuava a empregar dois terços da população e os centros urbanos eram pequenos e esparsos. Durante esse período, diversas tentativas de revolução nacionalista e liberal procuraram efetivar a unificação, mas não alcançaram êxito por causa da dura oposição dos governos austríaco e prussiano. No entanto, essas tentativas contribuíram para ampliar a consciência nacional que, aliada às transformações econômicas e ao papel crescente da classe média, somou características especiais à revolução de 1848 .

Em fevereiro desse ano, começaram as manifestações na Alemanha. O objetivo era a unificação com vistas ao fim da preponderância da Áustria e à extinção das soberanias principescas. Apesar de terem sido feitas reformas nos estados alemães, rumo à unificação, pouco a pouco a Assembleia perdeu o apoio popular e a contrarreforma tomou a ofensiva. Em 1851, nada mais restava do movimento de 1848.

Em 1866, Otto von Bismark, chanceler da Prússia, propôs a reorganização da Confederação Alemã com a exclusão da Áustria, desencadeando a Guerra Austro-Prussiana, que criou a Confederação Alemã do Norte com a vitória da Prússia. Finalmente, a unificação consolidou-se com a vitória da Prússia sobre a França na Guerra Franco-Prussiana em janeiro de 1871, que contou com o coração de Guilherme I como imperador do Segundo Reich (Bandeira, 1995). 
Durante todo esse processo de unificação, o território alemão sofreu principalmente com a falta de terras para atender às necessidades de uma população cada vez maior. $\mathrm{O}$ avanço do capitalismo também colaborou para a expulsão de muitos alemães de sua terra natal, e, muitos deles, encontraram no Brasil sua segunda pátria, como já vimos anteriormente.

As colônias alemãs no sul do Brasil eram predominantemente agrícolas, e formou-se na Alemanha uma forte corrente para apoiar seu desenvolvimento, para que, mais tarde, essas colônias pudessem fornecer à pátria-mãe produtos primários de alimentação.

Aliás, as notícias do interesse da Alemanha por esse território brasileiro foram muito marcantes no final do século XIX. O interesse do Estado alemão em constituir uma pátria-filha no Hemisfério Sul era muito grande. ${ }^{1}$ A partir de 1889, a perspectiva da derrubada da monarquia no Brasil levantou a hipótese de que o Brasil poderia se dividir em duas ou mais repúblicas e que essa separação ocorreria a partir dos estados do sul do Brasil. O governo alemão entusiasmouse com a ideia de que um Estado alemão se organizasse na região do Rio Grande do Sul e de Santa Catarina, ou, pelo menos, que uma nova república formada por esses estados recebesse forte influência do governo alemão.

Após 1890, essa ideia começou a proliferar na Alemanha, a partir de publicações na imprensa sobre a guerra civil no Rio Grande do Sul. A perspectiva era de que iria resultar na secessão, mas isso não aconteceu, e as expectativas dos alemães de constituírem uma pátria-filha além do oceano foram adiadas.

1 O plano alemão de conquista do mundo não foi uma criação do nazismo. O nacional-socialismo alemão, desde 1740, com o imperador Frederico II, já desenvolvia planos de se apoderar de diversos territórios. Em 1911, Otto Richard Tannenberg também manifestou seus planos pangermanistas no livro A grande Alemanha, a obra do século XX, onde apresenta o mapa da América do Sul no ano de 1950, após a concretização de seus planos. 
Por volta de 1900, a imprensa da Europa e dos Estados Unidos noticiou a pretensão da Alemanha de apoderar-se do território no sul do Brasil. A ideia era reforçada toda vez que chegavam notícias de que os alemães e seus descendentes no Rio Grande do Sul cultivavam a homogeneidade étnica e cultural de sua terra natal (idem).

Com base nesse cenário, podem-se discutir as relações entre o Brasil e a Alemanha após a ascensão do Partido Nacional-Socialista ao poder alemão.

Como descreve René Gertz (1987), a primeira iniciativa concreta que demonstra o interesse alemão pelo Brasil após a unificação ocorreu em 1934 sob o pretexto de assuntos econômicos. Foram firmados inúmeros acordos econômicos que em muito beneficiaram o Brasil e preocuparam os Estados Unidos, principalmente porque, depois da ascensão dos nacional-socialistas ao poder alemão, as relações entre Brasil e Alemanha se intensificaram consideravelmente.

O governo Vargas demonstrava uma simpatia crescente pelo regime nacional-socialista alemão, despertando interesse e colaboração até mesmo da polícia brasileira que, além de colaborar com a Gestapo, enviou seus homens para serem treinados pela polícia alemã. Durante esse período, foram criados institutos germano-brasileiros de preservação da língua e cultura alemã no País - como em São Paulo e no Rio de Janeiro -, o que demonstrava uma influência dos teutos na vida econômica, social e política nacional.

Essa harmonia entre teutos e brasileiros, Alemanha e Brasil, não durou muito tempo: a partir de 1938, os ingleses e norte-americanos extremamente preocupados com essa relação abalaram a aliança, chamando atenção dos brasileiros para o "perigo alemão": os alemães pretendiam apoderar-se do território brasileiro partindo do Rio Grande do Sul, pois era a região que havia sofrido maior influência dos povos germânicos. $\mathrm{O}$ interesse da Alemanha pelo território do sul do Brasil já era conhecido desde as primeiras décadas 
da colonização alemã no País, principalmente por causa de sua posição geográfica e influência na América Latina. É claro que a perpetuação da língua e dos costumes alemães naquele território reforçou o interesse.

A ideia do "perigo alemão" crescia à medida que o estado do Rio Grande do Sul tornava-se mais forte e influente em território nacional, e a figura de Vargas contribuiu muito para esse fortalecimento. Em muitas escolas primárias do Rio Grande do Sul e de Santa Catarina, o alemão era ensinado como idioma obrigatório nas cidades colonizadas por alemães, até os poucos negros existentes falavam o alemão e sentiam-se como "bons alemães". Além disso, os boletins divulgados por igrejas, clubes e pela imprensa dessas localidades eram escritos nesse idioma. Na verdade, até hoje são encontrados lugares no Rio Grande do Sul e Santa Catarina onde as pessoas utilizam o alemão no comércio, nos bares, nas praças (Medina, 1997).

Considerando esse retrato da sociedade alemã durante a década de 1930 no Brasil, pode-se compreender o porquê de o nacional-socialismo e os partidários de Hitler terem encontrado terreno fértil no território brasileiro.

Sobre esse ponto, Ribeiro (1995, p.440) afirma o seguinte:

Essa situação de marginalidade étnica dos núcleos de colonização, principalmente dos alemães, japoneses e italianos, foi explorada antes e durante a última guerra mundial pelos governos dos seus países de origem, criando graves conflitos de lealdade étnico-social. Com esse objetivo, os movimentos nazista e fascista bem como o governo japonês montaram aparatosos serviços de propaganda e estimularam o surgimento de organizações terroristas dedicadas a uma intensa doutrinação ideológica, nacionalista e racista.

O que não se pode esquecer é que muitos alemães deixaram sua pátria por causa das péssimas condições de vida em que se encontravam, continuando a cultivar o respeito pela 
terra-mãe em um período em que a crueldade do nazismo ainda não havia sido revelada.

A partir desse momento, vários movimentos políticos, militares e sociais originários do sul foram interpretados como atividades dos nacional-socialistas alemães, e há estudos como o de Jürgen Hell (1938) que revelaram que aqueles movimentos pretendiam criar uma "Nova Alemanha” no sul do Brasil. No livro Gespräche mit Hitler, de 1940, Hermann Rauschning declara obter informações do mais alto escalão nacional-socialista, em que a intenção de anexar o sul do Brasil aos projetos do nacional-socialismoé confirmada, declarando que o Führer planejava a conquista dessa área. Acreditava-se que a conquista poderia ser feita até sem violência, utilizando as "armas invisíveis" da confiança de Hitler: a fidelidade dos teutos em solo brasileiro para com a Alemanha. Há até quem suponha, se essa informação estivesse correta, que, além de manter uma relação oficialmente amigável com o Brasil, os alemães deveriam ter um programa para organizar e preparar a população de origem alemã para a execução de tal objetivo.

No entanto, independentemente dessa organização, o que poderia estar nos planos de Hitler seria a confirmação do caráter étnico (völkisch) na política exterior nacionalsocialista: estabelecer influência ou até mesmo domínio sobre todas as regiões onde se encontravam alemães e seus descendentes.

Os reflexos da tomada do poder pelos nazistas na Alemanha também atingiram os teutos no Brasil.

Os representantes nazistas instalaram-se nas colônias alemãs em várias cidades onde residiam os teutos e, a partir de atividades partidárias, interferiram nas decisões políticas e culturais de suas cidades ou comunidades. $\mathrm{O}$ grande objetivo dos partidários nazistas no sul do Brasil era a preservação da identidade étnica dos teutos longe de sua pátria de origem. 
Como exemplos desse discurso, destacam-se dois trechos da tese do Círculo Teuto-Brasileiro de Trabalho, ${ }^{2}$ de autoria de Rudolf Batke em 1935:

O povo alemão não é somente um conceito de Estado, válido para a Alemanha, e que abrange os súbditos do Estado alemão, mas sim um conceito de homens, independentes da cidadania, e que se deriva do sangue, da espécie, da cultura e da língua. Quem for de sangue alemão e congênere, se confessar adepto de nossa cultura e língua e do povo alemão quanto à espécie, esse também pertence ao povo alemão, embora seja cidadão de um outro país. (Py, 1942, p.23)

[...] Nenhum outro povo tem uma concepção étnica do mundo; somente o nosso. Nenhum outro povo lutou com tão admirável energia e consciência contra toda influência destruidora da etnia, como o nosso na Alemanha. Estamos no início e não no fim! $O$ povo alemão está começando a viver e a fazer história como unidade étnica. Temos motivos para capitular diante de outros povos, quando fazemos parte de um povo tão jovem? Não, nós temos a grande missão de também iniciarmos no Brasil o nosso rumo como grupo étnico. Os senhores, porém, foram eleitos para constituir a vanguarda e aplainar o caminho, a sua geração iniciará com passo firme e vontade férrea a nova época da história étnica no Brasil. Deposito toda a minha confiança na jovem geração teuto-brasileira. Os senhores devem ser os arautos de uma nova aurora de feitos étnicos no Brasil. (idem, p.24)

Bastide (1973, p.75) descreve como a variável étnica se tornava determinante nas lutas políticas, nas regiões colonizadas por alemães no Rio Grande do Sul: "No Rio Grande

2 O Círculo Teuto-Brasileiro de Trabalho foi fundado em 1935 por um grupo de brasileiros de origem alemã, que foram à Alemanha para dedicar-se a estudos profissionais. Era constituído de 44 membros: 13 alemães, 29 teuto-brasileiros e 2 teuto-paraguaios. 
do Sul, em que as comunidades alemãs eram mais isoladas, a luta dos partidos políticos toma muitas vezes o aspecto de luta entre nacionais e descendentes de imigrantes".

Era justamente esse elemento que gerava simpatia dos alemães no sul do Brasil para com os nazistas na Alemanha: a ideia de que eles nunca foram esquecidos pela pátria-mãe, mesmo estando além do oceano, e que os planos nazistas também atendiam às necessidades daqueles que aqui se estabeleceram. Para muitos, a "solidariedade do Führer era irrestrita", e, se eles estavam "reerguendo a Alemanha", também iriam lutar para melhorar as condições de vida dos teutos que estavam em outras nações.

O caráter de preservação étnica alemã dos nazistas era a grande arma dos partidários no sul do Brasil. Em nome da perpetuação dos vínculos culturais com a pátria de origem e com o propósito de fortalecer sua identidade étnica, os grupos nazistas no sul do Brasil realizavam encontros, reuniões e exigiam a publicação de seus artigos em jornais e boletins dirigidos aos teuto-brasileiros. Isso acontecia praticamente em todas as localidades onde residiam alemães.

Da mesma forma que crescia a propaganda nazista no Rio Grande do Sul, crescia também, e de forma muito intensa, a "difusão das ideias raciais alemãs". Frequentemente, as palavras judeu, mulato e negro eram usadas de forma depreciativa e insultuosa. De acordo com Gertz (1987, p.122), essas situações "eram frutos venenosos da teoria da superioridade da raça 'ariana', que germinava em território brasileiro, onde não houve jamais questões raciais”.

É claro que também havia divergências entre os partidários nazistas no Brasil (parteigenossen). Alguns grupos radicais não acreditavam que somente a conscientização sobre a importância da preservação da identidade étnica seria suficiente para unir e fortalecer a "comunidade alemã". Era preciso tomar o poder, controlar politicamente os teutos no País. Alguns grupos nazistas, principalmente de Porto 
Alegre, começaram a agir de maneira extremamente agressiva na tentativa de tomar o controle dos alemães.

Em 1935, a situação tornou-se tão crítica que o prestígio dos partidários nazistas começou a cair. Ocorreram prisões de partidários e simpatizantes por causa dos excessos e das agressões, o que acabou por provocar medo e discordância entre os teutos. Apesar de manterem uma simpatia declarada pela figura de Hitler e até de Mussolini, alguns alemães passaram a acreditar que a "campanha hitlerista ficava bem na Alemanha, mas nunca no Brasil” (idem, p.141).

Faz-se necessário diferenciar a forma de apoio ao nazismo dos alemães na Alemanha e dos teutos no Brasil.

A partir de 1930, o Partido Nazista cresceu muito na Alemanha, e, em razão da crise política e social em que o país se encontrava, o regime nacional-socialista passou a ideia de esperança, uma saída. Tratava-se de uma política de autoafirmação: o nacionalismo era a principal virtude e atribuía-se a crise não à burguesia, mas aos judeus e aos comunistas (acusados de ganância e exploração do povo, além de traição na Primeira Guerra Mundial, ocasionando assim a derrota da Alemanha). O discurso era de unificação do território alemão, e, segundo Hitler, "povos de mesmo sangue deveriam viver sob o mesmo Estado" e que "não era preciso lutar por igualdades de direitos na Alemanha, pois todos seriam iguais por pertencerem à raça ariana". O racismo ocultava as lutas de classe e justificava o imperialismo (Barcelos, 1973).

Nesse sentido, o apoio dos teuto-brasileiros ao movimento nazista não foi incondicional, principalmente porque não pretendiam voltar para a Alemanha, pois viviam bem no Brasil. Dessa forma, apenas o caráter étnico do nazismo foi levado adiante no Brasil, já que os exageros cometidos em nome da raça ariana não eram bem-vistos.

A atividade do movimento nazista no Brasil foi se enfraquecendo gradativamente, mas a simpatia pelos ideais e pela 
figura de Hitler nunca foi negada. Estimava-se que 80\% da população do sul do Brasil era nazista (Gertz, 1987), mas o número de partidários era pequeno, aproximadamente cinco mil em todo Brasil.

Segundo Gertz (1987), germanismo seria a melhor expressão para definir o sentimento dos teutos no Brasil durante o governo nazista na Alemanha. Com certeza, a ideia de constituir uma "Nova Alemanha" não era encarada como possibilidade real nem mesmo pelos partidários nazistas mais fervorosos. Mas, sem dúvida, o caráter étnico do nazismo, a preservação da identidade cultural do povo alemão em outras nações, a unidade, o crescimento e fortalecimento da identidade étnica alemã no sul do Brasil e o imenso respeito que sempre foi demonstrado pela pátria de origem caracterizaram esse germanismo. 


\section{Considerações finaIS}

Na relação entre dois universos, o nacional eo local (aqueles que se identificam como gaúchos), podem-se observar, pela trajetória histórica e cultural do Rio Grande do Sul, um distanciamento em relação ao nacional e um apego exacerbado ao local em que o gaúcho se está integrado. Para o grupo em questão, o "brasileiro" é o outro, o estranho, o distante que não faz parte daquele espaço e daquelas relações. Fala-se desse outro sem receios, é permitido fazer críticas, acusar e nominar: "O 'brasileiro' élento, safado, preguiçoso". Quando a referência se aproxima do universo local, essas características assumem outros sentidos, outras representações: "O povo gaúcho é trabalhador, esforçado, guerreiro. Eu moro aqui, eu sou daqui", um discurso que exclui e inclui.

A ideia de pertencimento nacional se esvai em fragmentos soltos, não assumindo proporções significativas na relação com o povo brasileiro e com a ideia do Brasil-Nação. Já a identificação com o estado do Rio Grande do Sul, com o ser gaúcho, assume proporções consideráveis, encontradas em todas as gerações. Trata-se de representações herdadas historicamente e mantidas como um elemento demarcador na relação com o restante do País. 
O "eu", assim como o "nós", tem sua identidade vinculada ao envolvimento com o ritual, criando uma diferenciação em relação ao "outro". Pensando no caso eleito como modelo para este estudo, pode-se dizer que a união em torno do CTG permite que os gaúchos se reconheçam como um grupo diante do restante da sociedade, ou seja, aqueles que seriam "os outros".

Estabelecido o debate em torno do separatismo, defronta-se, em geral, com posicionamentos polares. De um lado, a desqualificação de qualquer tipo de movimento separatista, assumindo o pressuposto de que se trata de bairrismo, de crime de lesa-pátria contra a realidade histórica definitiva da unidade territorial, cultural e linguística do Brasil. De outro, a defesa de particularidades geográficas, históricas, culturais e econômicas que poderiam ser mais bem administradas se o governo fosse autônomo e regional, sem subordinação ao governo federal considerado por eles desastroso.

No caso do Rio Grande do Sul, o que se constata através de anos de pesquisas é que, por trás do movimento separatista, estão, sobretudo, entrevistos problemas econômicos, políticos, sociais eétnicos, que destroem o sentimento de brasilidade daquela população, fazendo florescer o orgulho por uma terra que construiu sua história, muitas vezes, segundo seus porta-vozes, marginalizada pelo governo central. Para os separatistas, o único caminho para o Rio Grande do Sul superar essa crise é a autonomia política e administrativa.

O gaúcho é tão apegado a suas raízes e tradições, a sua história, a seu chão que construiu uma identidade étnica concentrada nesses elementos, conservando a ideia de origem comum. Um sentimento de Nação que rompe as barreiras do estado, onde o território é muito mais do que mera geografia: é uma herança.

O modelo que resulta da investigação de um grupo como o dos gaúchos separatistas pode funcionar como uma espécie de paradigma empírico. E aplicando-o como mo- 
delo a outras configurações separatistas mais complexas, é possível compreender melhor as características estruturais que elas têm e entender como, em condições diferentes, funcionam e se desenvolvem.

Compreender os movimentos separatistas é uma tarefa complexa que, com certeza, apenas se começa a vislumbrar. De modo geral, os movimentos separatistas correntes denunciam a situação vigente no País e, anunciam, talvez, a necessidade de se reformular o pacto federativo, para evitar seu possível colapso. 



\section{REFERÊNCIAS BIBLIOGRÁFICAS}

ALBERSHEIM, U. Comunidade teuto-brasileira. Rio de Janeiro: Centro Brasileiro de Pesquisa e Educação, 1962.

ALMEIDA, L. F. R. Ideologia nacional e nacionalismo. São Paulo: Educ, 1995.

ANDRADE, M. C. Raizes do separatismo no Brasil. São Paulo: Edusc, Editora UNESP, 1997.

ARARIPE, T. A. Guerra civil no Rio Grande do Sul. Rio de Janeiro: Laemmert Editores, 1891.

AZEVEDO, T. Gaúchos: a fisionomia social do Rio Grande do Sul. Salvador: Progresso, 1958.

BANDEIRA, M. O milagre alemão e o desenvolvimento do Brasil: as relações da Alemanha com o Brasil e a América Latina (1949-1994). São Paulo: Ensaio, 1995.

BARCELOS, S. Hitler. Rio de Janeiro: GB, 1973.

BARTH, F. Ethnic groups and boundaires: the social organization of culture difference. Bergen, Oslo: Universitetsforlaget; London: George Allen \& Unwin, 1969.

Grupos étnicos e suas fronteiras. In: POUTIGNAT, P.; STREIFF-FENART, J. Teorias da etnicidade. São Paulo: Editora UNESP, 1998.

BASTIDE, R. Brasil, terra de contrastes. São Paulo: Difel, 1973.

BOEIRA, N. et al. RS: cultura \& ideologia. Porto Alegre:

Mercado Aberto, 1980. 
CARDOSO, F. H. Capitalismo e escravidão no Brasil meridional: o negro na sociedade escravocrata do Rio Grande do Sul. Rio de Janeiro: Paz e Terra, 1977.

CHAUÍ, M. Convite à filosofia. São Paulo: Ática, 1988.

COHEN, A. Custon and politics in Urban África. London: Routledge and Kean Paul, 1969. Urban ethnicity. London: Tavistock, 1974.

DACANAL, J. H. Rio Grande do Sul: imigração e colonização. Porto Alegre: Mercado Aberto, 1992.

DALLARI, D. A. O Estado federal. São Paulo: Ática, 1986. ELIAS, N. O processo civilizador. Rio de Janeiro: Jorge Zahar, 1994. v.1-2.

Os alemães. A luta pelo poder e a evolução do habitus nos séculos XIX e XX. Rio de Janeiro: Jorge Zahar, 1997.

ERIKSEN, T. H. The cultural context of ethnic differences. Man, v.26, n.1, p.127-44, 1991.

FELDMAN-BIANCO, B. (Org.) A antropologia das sociedades contemporâneas. São Paulo: Global, 1987.

FERNANDES, F. Integração do negro na sociedade de classes: no limiar de uma nova era. São Paulo: Dominus Edusp, 1965.

Integração do negro na sociedade de classes: o legado da "raça branca". São Paulo: Dominus Edusp, 1965.

. O negro no mundo dos brancos. São Paulo: Difusão Européia, 1972.

FERREIRA FILHO, A. História geral do Rio Grande do Sul: 1503-1957. Porto Alegre: Globo, 1958.

FRANCO, J. N. Fundamentos do separatismo. São Paulo: Pannartz, 1994.

GEERTZ, C. A interpretação das culturas. Rio de Janeiro: Zahar, 1978.

. Nova luz sobre a antropologia. Rio de Janeiro: Zahar, 2001.

GERTZ, R. E. O fascismo no sul do Brasil: germanismo, nazismo, integralismo. Porto Alegre: Mercado Aberto, 1987.

GLAZER, N.; MOYNIHAN, D. P. Ethnicity, theory and experience. Cambridge: Harvard University Press, 1975. 
GORDON, M. Assimilation in american life. New York: Oxford University Press, 1964.

HALL, S. A identidade cultural na pós-modernidade. 3.ed. Rio de Janeiro: DP\&A, 1999.

HERMANN, L. Evolução da estrutura social de Guaratinguetá num período de trezentos anos. Revista de Administração (São Paulo), ano 2, n.5/6, p.1-326, 1948.

HOBSBAWM, E. J. A era das revoluções. 9.ed. São Paulo: Paz e Terra, 1996.

HOLANDA, S. B. Raízes do Brasil. São Paulo: Companhia das Letras, 1995.

LAPIERRE, J. W. Prefácio. In: POUTIGNAT, P.; STREIFF-FENART, J. Teorias da etnicidade. São Paulo: Editora UNESP, 1998.

LEITMAN, S. L. Raizes sócio econômicas da Guerra dos Farrapos: um capítulo da História do Brasil no século XIX. Rio de Janeiro: Graal, 1979.

LÉVI-STRAUSS, C. Raça e história. Lisboa: Presença, 1980.

LÉVI-STRAUSS, C. et al. Raça e história. In: Raça e ciência. São Paulo: Perspectiva, 1970.

LOVE, J. L. O regionalismo gaúcho. São Paulo: Perspectiva, 1975.

LUVIZOTTO, C. K. Migração e separatismo: alemães no processo de criação do movimento separatista no sul do Brasil. Marília, 2000. (Monografia apresentada ao Departamento de Ciências Sociais, UNESP, para obtenção do título de Bacharel em Ciências Sociais).

MAESTRI, M. Farroupilha: movimento das elites pastoris sulinas. Porto Alegre: UPF, 2001a.

A invenção da tradição: império e República Velha. Porto Alegre: UPF, $2001 \mathrm{~b}$.

MEDINA, S. Saga - Retrato das colônias alemãs no Brasil. São Paulo: Terra Virgem, 1997.

MOLON, N. D. Colapso da União: o separatismo no Brasil.

São Paulo: Pensieri, 1994.

MOURA, C. Rebelião na senzala: quilombos, insurreições, guerrilhas. São Paulo: Ciências Humanas, 1981. 
NEHAB, W. Anti-semitismo, integralismo e neo-nazismo. Rio de Janeiro: Freitas Bastos, 1988.

OBERACKER JÚNIOR, C. H. A contribuição teuta à formação da nação brasileira. Rio de Janeiro: GB, 1968.

OLIVEIRA, R. C. de. O índio e o mundo dos brancos. São Paulo: Difusão Européia do Livro, 1964.

PESAVEnTO, S. J. A Revolução Federalista. São Paulo: Brasiliense, 1983.

A Revolução Farroupilha. São Paulo: Brasiliense 1986.

PIERSON, D. Cruz das almas: a Brazilian Village. Washington: Smithsonian Institution, Institution of Social Anthropoly, 1951.

PIMPÃO, A. C. Vieram em busca de liberdade - Os 150 anos de imigração alemã no Brasil. Rio de Janeiro: Olímpica, 1974. POUTIGNAT, P.; STREIFF-FENART, J. Teorias da etnicidade. São Paulo: Editora UNESP, 1998.

PUJADAS, J. J. Etnicidad. Identidad cultural de los pueblos. Madrid: Eudema, 1993.

PY, A. S. A quinta coluna no Brasil: a conspiração nazista no Rio Grande do Sul. Porto Alegre: Globo, 1942.

RIBEIRO, D. O povo brasileiro: a formação e o sentido do Brasil. São Paulo: Companhia das Letras, 1995.

Os índios e a civilização: a interpretação das populações indígenas no Brasil moderno. São Paulo: Schwarcz, 1996.

RUBEN, G. R. A Teoria da Identidade na Antropologia: um exercício de etnografia do pensamento moderno. In: . Roberto Cardoso de Oliveira: homenagem. Campinas: Unicamp, IFCH, 1992. p.79-97.

RUBIM, C. R. Um pedaço de nossa história: historiografia da antropologia brasileira. BIB - Revista Brasileira de Informação Bibliográfica em Ciências Sociais (Rio de Janeiro), n.44, p.3-135, 1997.

SEYFERTH, G. A colonização alemã no Vale do Itajai-mirim. Porto Alegre: Movimento, 1974.

SPALDING, W. A epopéia Farroupilha. Rio de Janeiro: Biblioteca do Exército, 1963. 
VILLALBA, E. A Revolução Federalista no Rio Grande do Sul. Documentos e comentários. São Paulo: Laemmert Editores, 1897.

WAGLEY, C. Amazon town: a study of man in the tropics. New York: The Macmillan Company, 1953.

WILLEMS, E. A aculturação dos alemães no Brasil. Um estudo antropológico dos alemães e seus descendentes no Brasil. São Paulo: Companhia Editora Nacional, 1946.

Cunha, tradição e transição em uma cultura rural no Brasil. São Paulo: Diretoria de Publicidade Agrícola da Secretaria de Agricultura, 1947.

ZATTERA, V. E. Gaúcho: vestuário tradicional e costumes. Porto Alegre: Pallotti, 1995. 
SOBRE O LIVRO

Formato: $12 \times 21 \mathrm{~cm}$

Mancha: $20 \times 40,4$ paicas

Tipologia: Horley Old Style 10,5/14

$1^{\text {a }}$ edição: 2009

\section{EQUIPE DE REALIZAÇÃO}

Coordenação Geral

Marcos Keith Takahashi 
CULTURA

$\frac{\text { ACADÊMICA }}{\varepsilon d i t o t a}$ 